\title{
APPEARANCE, DISTRIBUTION, AND GENETIC DISTINCTIVENESS OF LONGMAN'S BEAKED WHALE, INDOPACETUS PACIFICUS
}

\author{
Merel L. Dalebout \\ School of Biological Sciences, University of Auckland, \\ Private Bag 92019, Auckland 1000, New Zealand \\ Graham J. B. Ross \\ 21 Pudney Street, Farrer, \\ Canberra ACT 2607, Australia \\ C. SCOTT BAKER ${ }^{1}$ \\ School of Biological Sciences, University of Auckland, \\ Private Bag 92019, Auckland 1000, New Zealand \\ E-mail: cs.baker@auckland.ac.nz \\ R. Charles Anderson \\ Marine Research Centre, \\ H. Whitewaves, Malé, Republic of Maldives \\ Peter B. Best \\ Mammal Research Institute, University of Pretoria, \\ Pretoria, 0002, South Africa \\ Victor G. COCKCROFT \\ Centre for Dolphin Studies, \\ Box 1856, Plettenberg Bay, 6600 South Africa \\ Harvey L. Hinsz \\ International School of Kenya, \\ P. O. Box 14103, Nairobi, Kenya \\ Victor Peddemors
}

School of Life and Environmental Sciences, University of Durban-Westville, Private Bag X54001, Durban 4000, South Africa

Robert L. Pitman

Southwest Fisheries Science Center,

National Marine Fisheries Service,

P. O. Box 271, La Jolla, California, U.S.A.

\footnotetext{
${ }^{1}$ Corresponding author. Authors are listed alphabetically after C. S. Baker.
} 


\begin{abstract}
Longman's beaked whale, Indopacetus pacificus, was known previously from only two skulls. Here we describe four new specimens of this species from strandings in the western and central Indian Ocean. Two juveniles, previously misidentified from external morphology as Hyperoodon planifrons, were identified as I. pacificus through diagnostic characteristics of mitochondrial $(\mathrm{mt})$ DNA sequences derived from the holotype of this species. Images of the external appearance and teeth of the species are presented for the first time. Comparison of the color pattern of these new specimens with that of "tropical bottlenose whales" sighted in the tropical Indian and Pacific oceans confirm that those unidentified whales represent $I$. pacificus. Moore (1968) erected a new genus, Indopacetus, for this species (described initially as Mesoplodon pacificus) based primarily on cranial morphology. Phylogenetic analyses of short mtDNA fragments available from the specimens known to date were unable to resolve the validity of this genus. However, the diagnostic osteological features highlighted by Moore (1968) for Indopacetus were also observed in the new specimens. Rib count and number of fused cervical vertebrae may also be diagnostic. Rostrum depth at mid-length and melon shape further distinguish this species from Mesoplodon beaked whales. As such, we see no reason on morphological grounds to overturn Moore's (1968) proposal that Longman's beaked whale is sufficiently distinct to be afforded its own genus.
\end{abstract}

Key words: molecular genetics, mtDNA, holotype, species identification, taxonomy, external appearance, osteology, distribution, tropical bottlenose whales.

Longman's beaked whale, Indopacetus pacificus, is considered one of the rarest of all cetaceans (Jefferson et al. 1993, Rice 1998). Only two specimens have been described to date: the holotype, a skull and mandible found beachcast at Mackay, northern Queensland, Australia in 1882 (Mesoplodon pacificus; Longman 1926), and a second skull and mandible found in a fertilizer factory in Danane, Somalia, in 1955 (Azzaroli 1968). Based on the holotype, Raven (1937) suggested that Longman's beaked whale was simply a larger Pacific form of True's beaked whale, M. mirus. McCann (1962c) disagreed and suggested instead that it represented the damaged skull of a female southern bottlenose whale, Hyperoodon planifrons. The discovery of the second specimen and a series of comprehensive morphological evaluations by Moore $(1957,1968,1972)$ refuted both hypotheses and confirmed the morphological distinctiveness of the species. Moore (1968) also suggested that Longman's beaked whale was sufficiently distinct from other ziphiid taxa to warrant the erection of a new genus, Indopacetus. Although accepted by some (e.g., Rice 1998), the validity of this genus is still in debate (e.g., Mead 1989a).

The external appearance of Longman's beaked whale remained unknown. Skull morphology and the original classification (Longman 1926) suggest that it may resemble a large beaked whale of the genus Mesoplodon (i.e., with a spindle-shaped body, a small head in relation to the thorax and abdomen, and without a distinct notch between the rostrum and gently sloping melon; Mead 1989a). Calculations based on skull dimensions indicate that the holotype (considered to be an adult male by Moore 1968) was $\sim 7 \mathrm{~m}$ in length (Pitman et al. 1999), slightly larger than Mesoplodon spp. Mörzer Bruyns (1971) suggested that unidentified "very large beaked whales" observed in the warmer waters of the Indian and Pacific oceans could be Longman's beaked whales. Whales similar to those he described have been sighted subsequently. They are similar in general body form and color pattern to 
southern bottlenose whales, $H$. planifrons, with an estimated adult length of 7-8 m (Pitman et al. 1999) and have been referred to as "tropical bottlenose whales." Melon shape is variable; larger than in Berardius, but less pronounced and bulbous than in Hyperoodon (Pitman et al. 1999). Analyses of size, scarring patterns, and distribution of sightings have provided additional support for the hypothesis that Longman's beaked whale and tropical bottlenose whales are one and the same (Ballance and Pitman 1998, Pitman et al. 1999).

Here we present information on four new specimens of Longman's beaked whale: two juvenile males stranded on the Indian Ocean coast of South Africa, an adult female stranded in the Republic of Maldives, and the skull of an adult assumed from its provenance to be from Kenya. The two juvenile specimens were initially misidentified as southern bottlenose whales $H$. planifrons from external morphology; one was described in some detail by Ross (1984). These specimens are here identified as I. pacificus through phylogenetic comparisons to a comprehensive DNA reference database for beaked whales (Dalebout 2002). The Maldivian specimen was identified as I. pacificus from external and skull morphology, and its species identity confirmed through genetic analyses. The new Kenyan skull was identified as I. pacificus based on morphology alone. This paper includes a genetic description of Longman's beaked whale, as well as discussion of the distribution, external appearance, and taxonomy of this species.

\section{METHODS}

\section{Material Examined}

Six specimens were examined. Numbers 1-2 were described previously, whereas numbers 3-6 are new specimens.

1. Skull and mandible (QM-J2016) held at the Queensland Museum, Brisbane, Australia. Collected in 1882 by E. W. Rawson from Mackay, Queensland, Australia $\left(21^{\circ} 10^{\prime} \mathrm{S}, 149^{\circ} 10^{\prime} \mathrm{E}\right)$. Holotype of Indopacetus pacificus. Described and named (Mesoplodon pacificus) by H. A. Longman in 1926. Considered likely to represent an adult male (Moore 1968).

2. Skull and mandible (MZUF 1956 [M4854]) held at the Natural History Museum, Zoological Section 'La Specola' at the University of Florence, Italy. This whale was found stranded near Danane, Somalia $\left(1^{\circ} 52^{\prime} \mathrm{N}, 45^{\circ} 02^{\prime} \mathrm{E}\right)$ by local fishermen in 1955 and taken to a nearby fertilizer factory for oil extraction and use as organic fertilizer. ${ }^{2}$ Skull and mandible described by Azzaroli (1968). Considered to represent a possible subadult female based on skull size and proportions in comparison to the holotype (Azzaroli 1968, Moore 1972).

3. Skull without mandible (OM7622) held at the National Museum of Kenya, Nairobi, Kenya. Discovered at the International School of Kenya, Nairobi, Kenya by H. L. Hinsz. Collected from an unknown location on the Kenya coast ca. 1968 (based on accounts from long-time workers at the school, which was moved to Nairobi in 1968, who remember this distinctive large skull as one of two skulls which framed the wall where movies were shown). Sex unknown.

4. Several ribs and vertebrae (PEM292) held at the Port Elizabeth Museum, South Africa. Complete specimen collected by G. J. B. Ross from Blythesdale Beach,

\footnotetext{
2 Personal communication from P. Agnelli and U. Funaioli, Natural History Museum 'La Specola', University of Florence, Italy, e-mail, 23 October 2001.
} 
Natal, South Africa $\left(29^{\circ} 39^{\prime} \mathrm{S}, 31^{\circ} 36^{\prime} \mathrm{E}\right)$ on 7 November 1976. Total length of specimen, $291 \mathrm{~cm}$. Juvenile male (neonate). Collected by G. Thurmer, and dissected and described by Ross (1984) as Hyperoodon planifrons (original specimen code, PEM1520/30). Photographs were taken of the external appearance of this specimen when fresh and a detailed necropsy was performed on the body posterior to the head. However, the head was inadvertently disposed of following a freezer failure.

5. Skull, mandible, teeth, earbones, and ribs (PEM1960) held at the Port Elizabeth Museum, South Africa (registered as $H$. planifrons). Complete specimen collected by V. G. Cockcroft and V. Peddemors from Sodwana Bay, Natal, South Africa $\left(27^{\circ} 34^{\prime} \mathrm{S}, 32^{\circ} 41^{\prime} \mathrm{E}\right)$ on 5 August 1992 , with help from the staff of the KwaZulu-Natal Nature Conservation Services (formerly Natal Parks Board) and the Natal Sharks Board. Juvenile male. Total length of specimen, $363 \mathrm{~cm}$.

6. Skull, mandible, teeth, and postcranial material (no reference number) held at the Marine Research Centre, Ministry of Fisheries, Agriculture and Marine Resources, Malé, Republic of Maldives. Complete specimen (including the remains of a 104-cm long fetus) collected from Felidhu Atoll, Republic of Maldives $\left(3^{\circ} 26^{\prime} \mathrm{N}, 73^{\circ} 26^{\prime} \mathrm{E}\right)$ on 17 January 2000 , by R. C. Anderson with help from the staff of the Marine Research Centre. Adult female. Total length of specimen (curvilinear), $596 \mathrm{~cm}$. The skeletal material obtained from this specimen will be transfered to a dedicated display hall in the Republic of Maldives in due course.

The comparative rarity of beaked whales and their often non-distinct morphological features are a general problem with the identification of species in this group. To assist in species identification, a DNA reference database of mitochondrial $(\mathrm{mt})$ DNA control region and cytochrome $b$ sequences has been compiled for all 21 described species of beaked whales (Dalebout 2002). All specimens in this database, which includes the holotype of Longman's beaked whale (QM-J2106), are validated by diagnostic skeletal material or photographic records held in museums and archives. Through phylogenetic comparisons to such a reference database, the species identity of unknown "test" specimens can be determined (e.g., Henshaw et al. 1997, Dalebout et al. 1998). Using this database, phylogenetic analyses were used to confirm the identity of three of the four new Longman's beaked whales. To date, the Kenyan specimen has not been sampled for genetic analysis due to logistical difficulties.

Morphological comparisons were made to other ziphiid species. External measurements were taken following Norris (1961) for the two South African juveniles (PEM292 and PEM1960) by Ross and Cockcroft, respectively, and for the Maldivian adult female by Anderson. Cranial measurements and mandibular measurements following Moore (1972), were taken for specimens from Queensland, Somalia, Kenya, the Maldives, and South Africa (PEM1960) by several authors, together with limited information on tooth dimensions (see Tables 3 and 4 for details).

\section{DNA Extraction and Sequencing}

A hand-held electric drill with a 2-mm diameter drill bit was used to obtain 0.01-0.02 g of bone or tooth powder from each specimen. The drill site was cleaned with $70 \%$ ethanol to remove dust and particulate matter prior to drilling (see Pichler et al. 2001 for further information). The silica-based method of Höss and Pääbo (1993) was used to extract DNA from this material, with the addition of a proteinase-K digestion step at the beginning of the procedure to increase yields (Matisoo-Smith et al. 1997). Previously, these methods had been used to extract 
DNA from bone powder from the holotype specimen. In addition, the Chelex method (Walsh et al. 1991) as modified by Baker et al. (1996) was used to extract DNA from degraded soft tissue from the Maldivian specimen and from the fetus that it carried. Given the non-recombining, maternal mode of inheritance of the mitochondrial genome (e.g., Wilson et al. 1985), the Maldivian specimen and her fetus were treated as a single individual in these analyses.

Using the Polymerase Chain Reaction (PCR), short segments of the $5^{\prime}$ end of the mtDNA control region and $5^{\prime}$ end of the cytochrome $b$ gene were amplified from all five specimens (see Appendix for primer sequences and further information). Sequences from these specimens were aligned by eye to the reference sequences comprising the beaked whale reference database (Dalebout 2002). These sequences have been submitted to Genbank (Accession Nos: AY162435-AY162444). The aligned reference sequence files and further information regarding reference specimens are available from the website http://www.dna-surveillance.auckland.ac.nz.

\section{Phylogenetic Analyses}

Phylogenetic relationships among the mtDNA control region and cytochrome $b$ sequences from the new "test" specimens, the Somali specimen (MZUF 1956), and reference sequences from all 21 described beaked whale species in the database (including the holotype of $I$. pacificus) were reconstructed using neighbor-joining (NJ), maximum parsimony (MP), and maximum likelihood (ML) methods. For each locus, the length of the multiple sequence alignment used was set by the longest putative $I$. pacificus sequence available. The robustness of the resulting trees was evaluated by bootstrap resampling of the data. Baird's beaked whale, B. bairdii, was used as an outgroup as it likely represents the basal genus in this family (e.g., Dalebout et al. 1998). Inclusion of more distant outgroup taxa (i.e., representatives from other cetacean families) did not affect the branching patterns at any of the nodes relevant to this paper (Dalebout 2002). All phylogenetic analyses were conducted using the program PAUP* 4.0b10 (Swofford 1999). See Appendix for details of analysis parameters and settings.

\section{RESULTS}

\section{DNA Sequence Data}

Fragments of the mtDNA control region ranging in length from 226 to 409 base pairs (bp) and fragments of the cytochrome $b$ ranging in length from 130 to $289 \mathrm{bp}$ were sequenced successfully from all five specimens available for genetic analysis (Table 1). Attempts to amplify longer sequence fragments were unsuccessful, as expected from DNA extractions from bone, tooth, or degraded soft tissue (e.g., Höss and Pääbo 1993). The DNA sequences obtained from the tooth of the Maldivian female and the soft tissue from her fetus were identical over the segment represented for both. Attempts to amplify these short mtDNA fragments from the decomposed soft tissue of the Maldivian female were unsuccessful. As slightly longer sequences were obtained from the fetal material, only these were included in the analyses.

\section{Molecular Genetic Species Identification}

In phylogenetic analyses of mtDNA control region ( $415 \mathrm{bp}$ alignment) and cytochrome $b$ (268 bp alignment) sequences, the Somali specimen (Azzaroli 1968), 


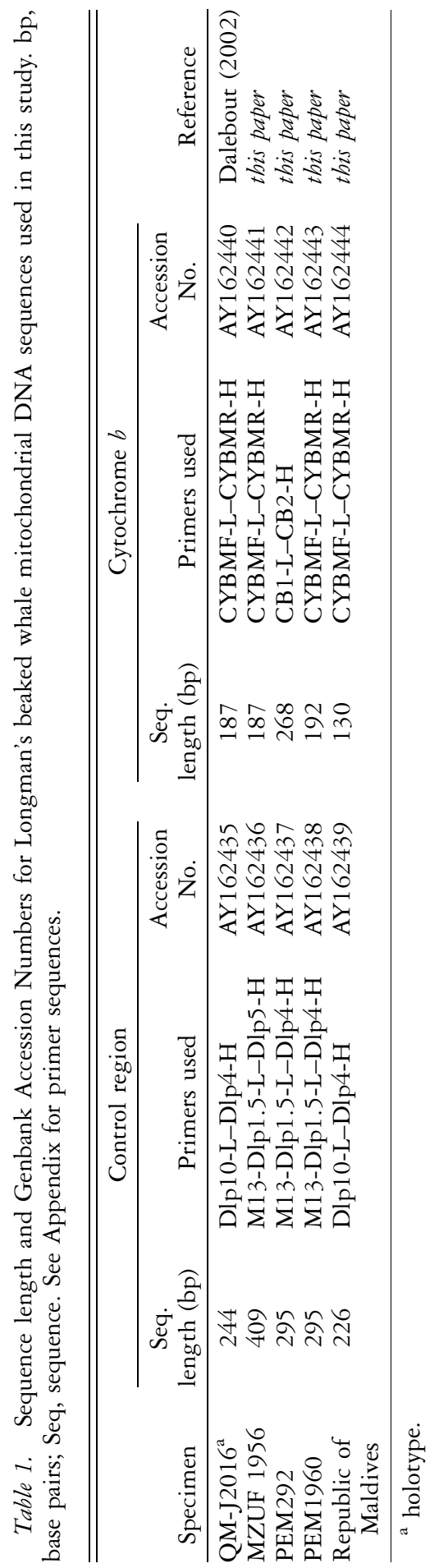




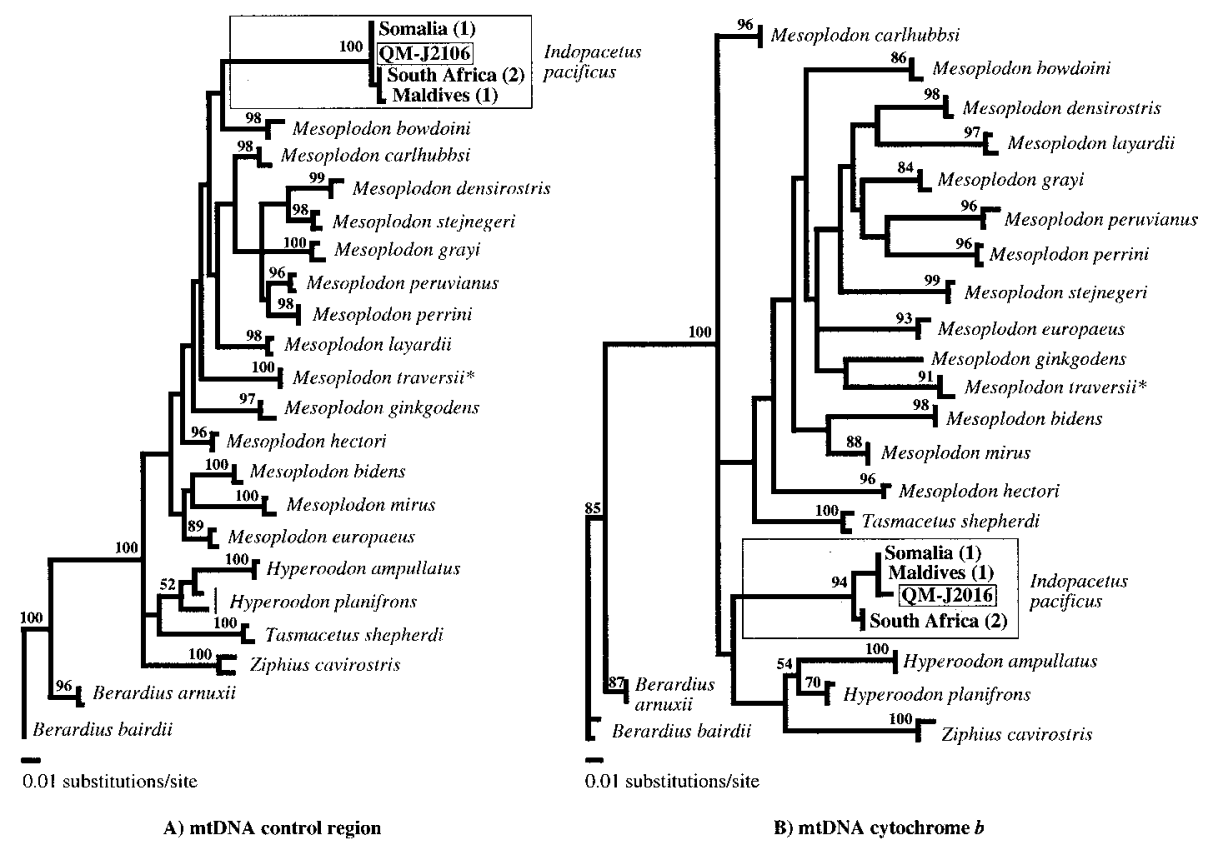

Figure 1. Phylogenetic relationships among the 21 described species of beaked whales (Ziphiidae) reconstructed using ML methods, based on A) a 415 bp alignment of mtDNA control region sequences and, B) a 268 bp alignment of mtDNA cytochrome $b$ sequences. Nos. above internal nodes indicate bootstrap values $>50 \%$ from 200 ML resamplings of these data. All species are represented by two reference specimens where possible. In each figure, the gray box highlights the specimens of Longman's beaked whale, within which the white box highlights the holotype. *Mesoplodon traversii $=M$. bahamondi; see van Helden et al. 2002 for details.

and the three new specimens from South Africa and the Maldives grouped closely with the holotype of Longman's beaked whale confirming that all five animals represented the same species (ML bootstrap scores-control region, 100\%; cytochrome $b$ 94\%; Fig. 1). The MP and NJ trees did not differ significantly from the ML trees shown at nodes relevant to this paper. All species-specific groupings were supported by high bootstrap scores $(>80 \%)$. Southern bottlenose whales, $H$. planifrons, were the exception to this trend due to a deep intraspecific divergence at these genes (Dalebout 2002). Although well suited to species identification, these short mtDNA sequences did not yield robust reconstructions of higher-level relationships among the Ziphiidae (i.e., most internal nodes were very short, with bootstrap scores $<50 \%$ ). Thus, no conclusions can be drawn from these trees about the validity of the genus Indopacetus. Note that while the genus Mesoplodon does not form a monophyletic clade in the cytochrome $b$ tree (Fig. 1B), nor was monophyly strongly supported by the control region tree (where Longman's beaked whale branches among the Mesoplodon spp.; Fig. 1A), robust phylogenetic reconstructions based on long sequences from more slowly evolving single copy nuclear loci (missing Longman's beaked whale) support the validity of this genus (Dalebout 2002). 


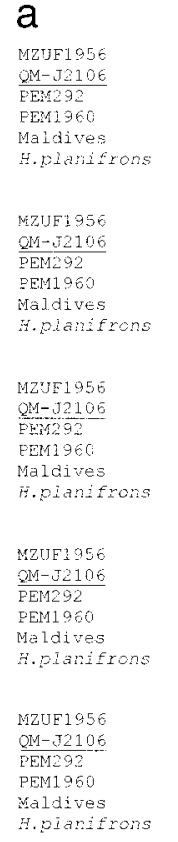

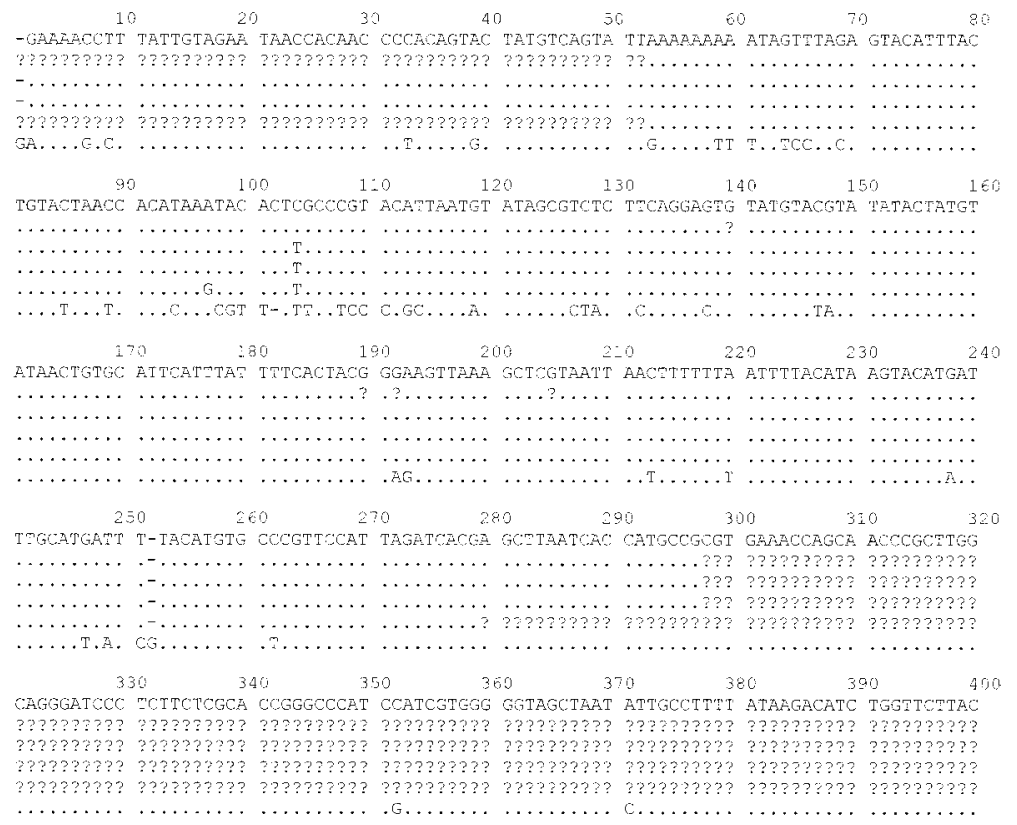

410

\begin{tabular}{|c|c|}
\hline MZUF 1956 & TTCAGE \\
\hline $61-02 \div 05$ & 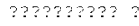 \\
\hline $\operatorname{Fen292}$ & ว???า????? \\
\hline FEMI 960 & ?????????? \\
\hline Maldives & ใ??ว??ว??ใ ? \\
\hline Holanifrons & $\ldots \ldots$ 프, \\
\hline
\end{tabular}

Figure 2. (a) Aligned mitochondrial DNA control region, and (b) cytochrome $b$ sequences for five of the six known specimens of Longman's beaked whale, labeled as in Table 1. Identity to the top sequence is indicated by dots. Position 1 of the control region alignment corresponds to first nucleotide of this locus, and to position 15891 of the fin whale Balaenoptera physalus mtDNA genome (Arnason et al. 1991). Position 1 of the cytochrome $b$ alignment corresponds to the 15 th nucleotide (third position) of the cytochrome $b$ gene, and to position 14627 of the fin whale mtDNA genome (Arnason $e t$ al. 1991). Sequences from the morphologically similar southern bottlenose whale $H$. planifrons (AUNZ Hpl01) are included in both alignments for comparison. Dash, nucleotide deletion; question mark, missing data.

\section{Intra- and Interspecific Divergence}

At the mtDNA control region, the holotype (QM-J2106) and the Somali specimen (MZUF 1956) shared the same haplotype and differed by one transition substitution from the shared haplotype of the two South African specimens (PEM292 and PEM1960). The haplotype represented by the Maldivian specimen differed by one transition substitution from the haplotype of the South African specimens (Fig. 2a). Over the maximum sequence length available (409 bp; MZUF 1956 [415 bp as aligned to other ziphiid species]), which covers the most variable portion of the ziphiid control region (Dalebout 2002), I. pacificus differed from all other beaked whales by an average of $11.01 \%$ (range: $8.68 \%$, from Hector's beaked 


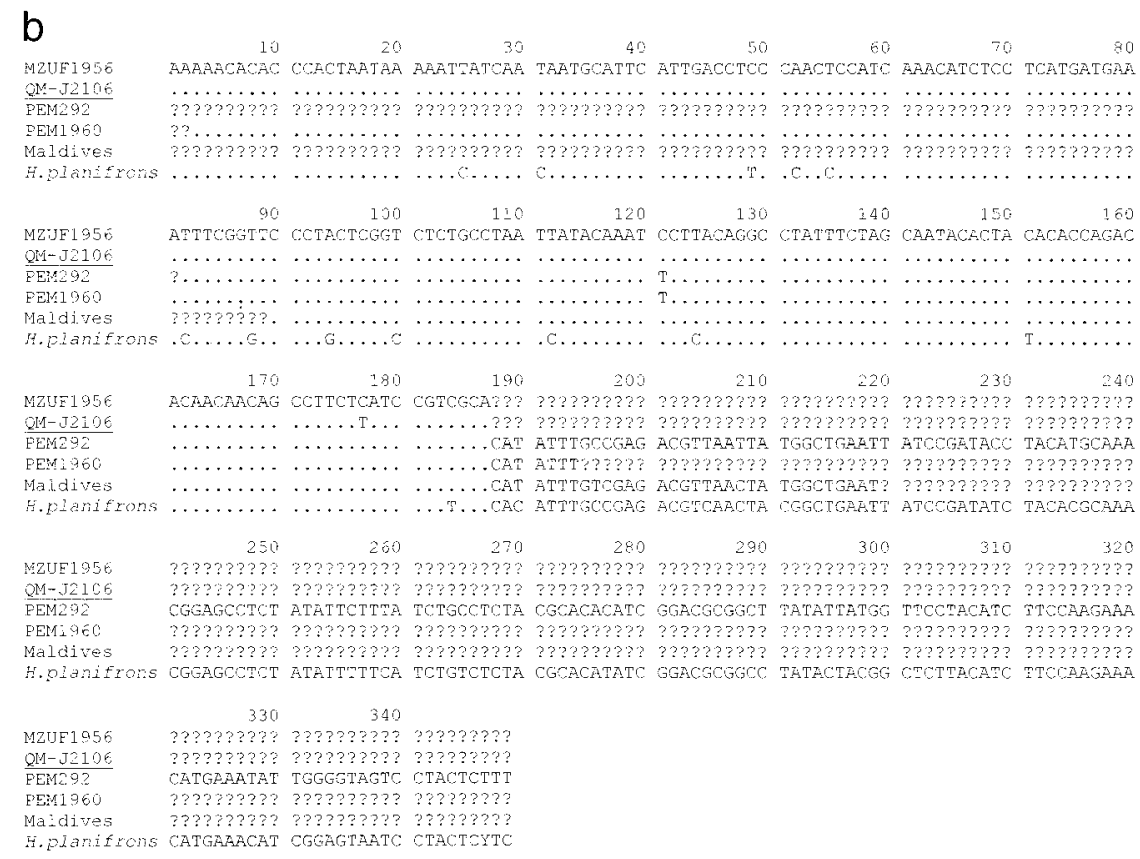

Figure 2. Continued.

whale $M$. hectori, to $13.12 \%$ from Arnoux's beaked whale $B$. arnuxii). At the mtDNA cytochrome $b$, the Somali and Maldivian specimens shared the same haplotype, which differed from that of the holotype specimen by one nonsynonymous substitution. The haplotype possessed by the two South African specimens differed from that of the holotype by two transition substitutions (third position synonymous, first position non-synonymous; Fig. 2b). Over the maximum sequence length available (268 bp; PEM292), I. pacificus differed from all other beaked whales by an average of $15.16 \%$ (range: $11.74 \%$ from Hubbs' beaked whale M. carlhubbsi, to $19.51 \%$ from the ginkgo-tooth beaked whale M. ginkgodens). Similar patterns of divergence (i.e., relatively low within species and relatively high between species) have been observed for both loci among other ziphiid taxa, including intraspecific non-synonymous substitutions at the cytochrome $b$ (Dalebout 2002, Dalebout et al. 1998).

\section{Morphological Description}

Here we present the first images of the external appearance and teeth of confirmed specimens of this species. The only previously published figures of known Longman's beaked whale are of the crania and mandibles of the holotype and Somali specimens (Longman 1926; Azzaroli 1968; Moore 1968, 1972). No teeth were found with either specimen. For clarity, Ross' (1984) description of the South African specimen, PEM292, is repeated here.

External appearance - Overall, the body form of juvenile Longman's beaked whales 
was similar to, though more slender than, juvenile $H$. planifrons of a similar size (Fig. 3, PEM292, $291 \mathrm{~cm}$ total length [TL]; PEM1960, $363 \mathrm{~cm}$ TL; for comparison see Fig. 4, H. planifrons AUNZ Hpl01, $300 \mathrm{~cm}$ TL; AUNZ Hpl03, $368 \mathrm{~cm}$ TL). The small dorsal fin was set far back on the body and sloped rearwards on its anterior edge with a markedly falcate trailing edge. The melon was well rounded in profile and sloped evenly to meet the rostrum at $\sim 75^{\circ}$ (Fig. 3E, I). The beak was short and stout in juveniles of both $I$. pacificus and $H$. planifrons, but in the latter species the melon was more swollen and distinctly broader antero-dorsally (e.g., Fig. 4C).

In profile, the melon of the Maldivian adult female was similar in form and size to that of the South African juveniles. The melon rose above the level of the neck over the cranium and descended to meet the rostrum at $\sim 75^{\circ}$ (Fig. 5A, arrow 1). In contrast, the melon meets the rostrum at $\sim 90^{\circ}$ or more in $H$. planifrons (e.g., Fig. $4 \mathrm{C}$, arrow). The rostrum was moderately long and slender. Taking into account distortion due to decomposition and associated swelling, the Maldivian female nonetheless appeared similar in overall robustness to Hyperoodon and Ziphius (Fig. 5B). In comparison, Mesoplodon spp. are generally laterally compressed and deepbodied (e.g., see Mead 1989a, fig. 1). The melon was also larger and more pronounced than that of Mesoplodon spp. There was no evidence of tooth eruption in life (Fig. 5A, arrow 2) despite careful checking during the examination of the stranding. Other observed features common to all ziphiids include the lack of a notch in the tail fluke and small pectoral fins that tuck into well-defined depressions in the body wall (termed "flipper pockets" by Mead et al. 1982). These flipper pockets were visible in the calves (Fig. 3B, D, I) but not the adult female (Fig. 5), probably due to decomposition and bloating. The horns of the crescentshaped blowhole pointed anteriorly (only those of Berardius spp. point posteriorly). External measurements are given in Table 2.

Color pattern - Much of the following description of neonate-juvenile color pattern is based on the South Africa specimen, PEM292, which was examined when fresh (Ross 1984; Fig. 3A-H). Posterior to the blowhole, the entire dorsal surface was black, becoming dark gray laterally prior to merging smoothly with the white of the ventral surface. Posterior to the eye, the black of the dorsum extended ventrally in a broad band towards the anterior insertion of the flipper, becoming gray as it did so (Fig. 3A, arrow 1). This feature appears to be absent in $H$. planifrons (e.g., Fig. 4A, arrow), but may occur in Tasmacetus (see Baker 1999, p. 87). A dark band of black extended ventrally from the blowhole to join a black patch surrounding the eye. A small lighter patch was embedded in the area of dark pigmentation posterior to the eye (Fig. 3A, arrow 2). Anterior to the blowhole, dark gray pigment extended along the mid-line as far as the apex of the melon (Fig. 3E; arrow 1), in an antero-lateral streak over the upper half of the melon and anterior to the eye (Fig. 3E; arrow 2). Much of the upper jaw and dorsal margin of the lower jaw tip were black (Fig. 3A, E;

Figure 3. External appearance of juvenile Longman's beaked whales; PEM292: (A) lateral view of body, scale bar $=30 \mathrm{~cm}$; (B) oblique ventral view, scale bar $=10 \mathrm{~cm}$; (C) ventral view of flukes, scale bar $=10 \mathrm{~cm}$; (D) left flipper, scale bar $=10 \mathrm{~cm}$; (E) lateral view of head, scale bar $=5 \mathrm{~cm}$; (F) oblique ventral view of head, scale bar $=5 \mathrm{~cm}$; $(\mathrm{G})$ dorsal view of head, scale bar $=10 \mathrm{~cm}$ (arrow indicates right anterior tip of blowhole); $(\mathrm{H})$ dorsal fin, scale bar $=10 \mathrm{~cm}$; PEM1960 (I) lateral view of body, scale bar $=50 \mathrm{~cm}$; Photocredits: (A-H) G. J. B. Ross, (I) V. Peddemors. Arrows (except G), see text for discussion. 


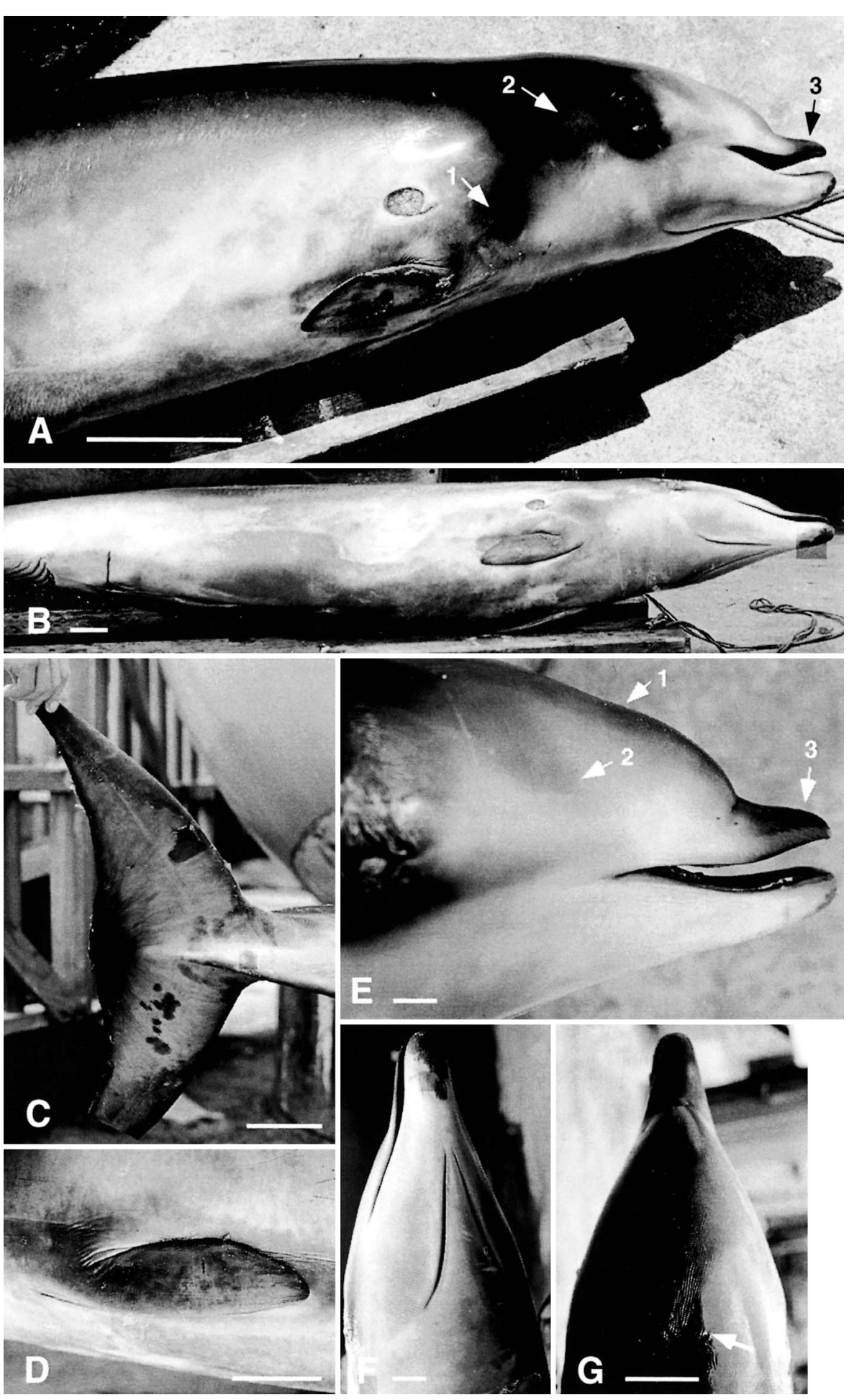




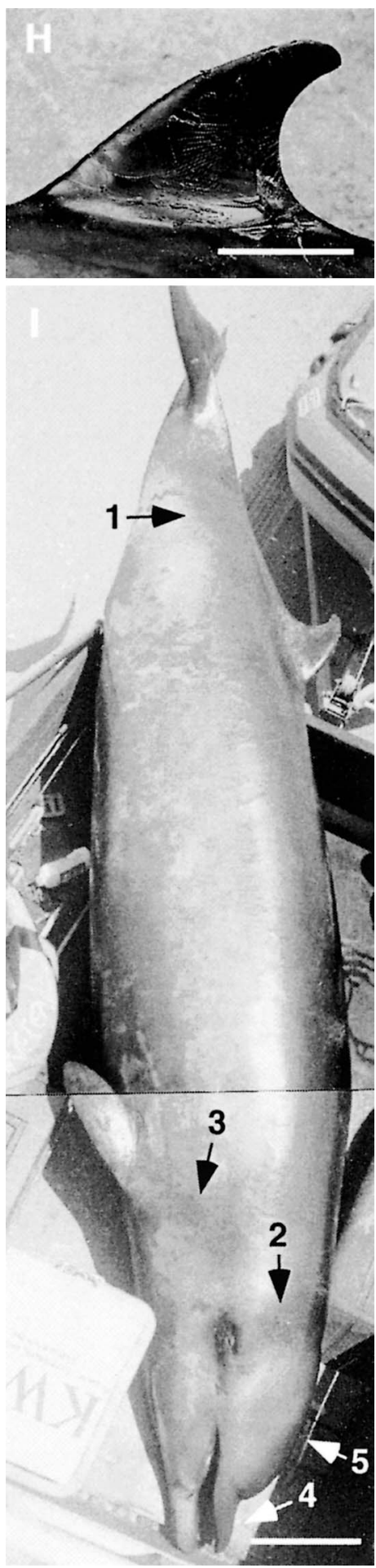

Figure 3. Continued. 


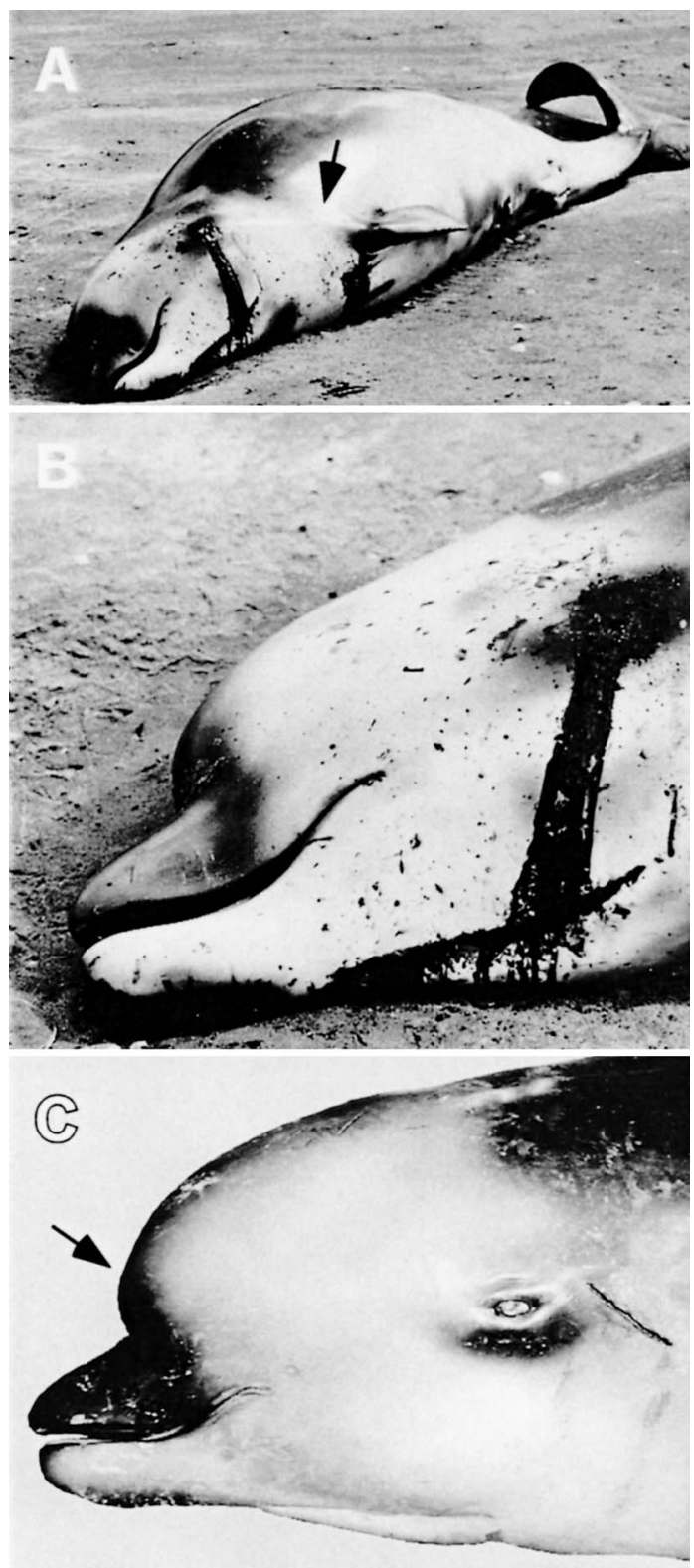

Figure 4. External appearance of juvenile southern bottlenose whales, Hyperoodon planifrons, from strandings in New Zealand; AUNZ Hpl03 (Ohope, Whakatane, 1 April 1996. Female; TL $368 \mathrm{~cm}$ ): (A) antero-lateral view of body; (B) lateral view of head. AUNZ Hpl01 (Orere Pt., Firth of Thames, 7 December 1994. Female; TL $\sim 300 \mathrm{~cm}$ ): (C) lateral view of head. Arrows, see text for discussion. Photocredits: (A-B) R. Tully, (C) T. Jones. 


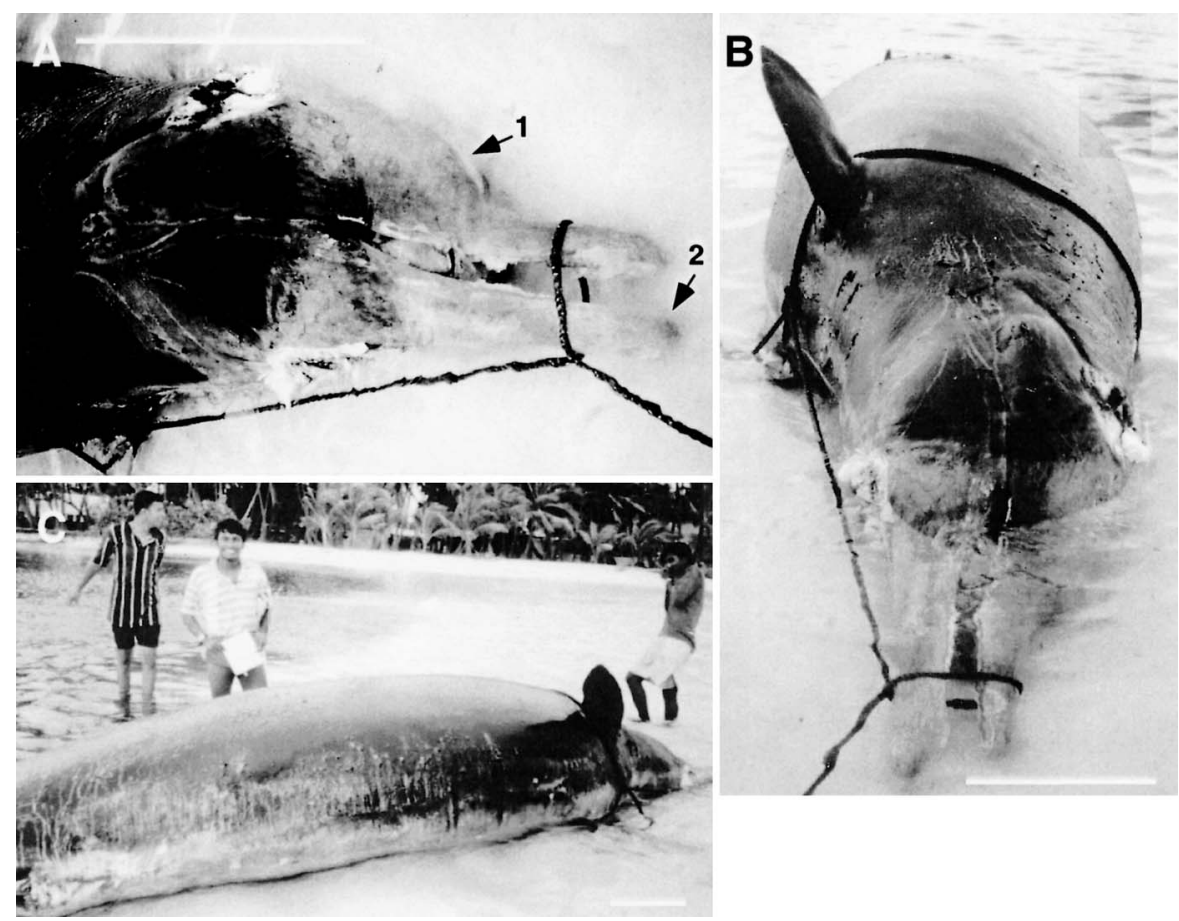

Figure 5. External appearance of adult female Longman's beaked whale; Republic of Maldives: (A) lateral view of head; (B) view of body from anterior perspective; (C) ventral view of anterior two-thirds of body. All scale bars $=50 \mathrm{~cm}$. Arrows, see text for discussion. Photocredit: A. Hafiz.

arrow 3 both figures), in contrast to the white of the rest of the face, lower jaw, and throat. The outer surface of the flippers was black, while the inner surface was white (Fig. 3D). The posterior margin and the anterior third of the dorsal fin were dark gray to black and enclosed a white blaze (Fig. $3 \mathrm{H}$ ). In the posterior half of the caudal peduncle, the dark gray of the dorsal margin extended to the mid-depth of the peduncle. Ventrally, the skin in this region was pigmented with fine flecks and streaks of dark and pale gray. The dorsal surface of the flukes was black. On the ventral surface, the margins of the flukes were black. In the middle third of the trailing edge of the flukes, the dark margin broadened anteriorly as far as the junction of the caudal peduncle and the fluke surface. From the anterior margin, numerous fine gray streaks radiated across the white background of the ventral surface as far as the leading edge of the flukes (Fig. 3C).

Much of the coloration of the second juvenile (PEM1960) was lost though exposure to the sun. However, elements of the color pattern described for PEM292 were discernible, including the extension of the dark dorsal pigmentation to mid-depth of the body and more posteriorly onto the ventral caudal peduncle (Fig. 3I, arrow 1), the dark strips linking the dorsal pigmentation with the eye patch and the flipper (Fig. 3I, arrows 2 and 3), the dark upper jaw, and white lower jaw (Fig. 3I, arrow 4). Overall, the light appearance of the head and melon was clearer in this animal than in PEM292 and 
Table 2. External measurements for Longman's beaked whale. Where two numbers are given, the first is from the right hand side and the second from the left hand side. \% TL, percentage of total length.

\begin{tabular}{|c|c|c|c|c|c|c|}
\hline & \multicolumn{2}{|c|}{$\begin{array}{l}\text { South Africa } \\
\text { PEM } 292 \\
\end{array}$} & \multicolumn{2}{|c|}{$\begin{array}{l}\text { South Africa } \\
\text { PEM1960 }\end{array}$} & \multicolumn{2}{|c|}{$\begin{array}{c}\text { Maldives } \\
-\end{array}$} \\
\hline & $\mathrm{cm}$ & $\% \mathrm{TL}$ & $\mathrm{cm}$ & $\% \mathrm{TL}$ & $\mathrm{cm}$ & $\% \mathrm{TL}$ \\
\hline Sex/age class & \multicolumn{2}{|c|}{ male/neonate } & \multicolumn{2}{|c|}{ male/juvenile } & \multicolumn{2}{|c|}{ female/adult } \\
\hline Total length & 291.0 & 100 & 363.0 & 100 & $596.0^{\mathrm{a}}$ & 100 \\
\hline Beak tip to centre of blowhole & 41.0 & 14 & 50.0 & 14 & - & - \\
\hline Beak tip to centre of eye & 43.0 & 15 & 54.5 & 15 & $100.0^{\mathrm{a}}$ & 17 \\
\hline Beak tip to apex of melon & 9.5 & 3 & - & - & - & - \\
\hline Beak tip to angle of mouth & 26.0 & 9 & 34.0 & 9 & - & _- \\
\hline $\begin{array}{l}\text { Beak tip to anterior insertion } \\
\text { of flipper }\end{array}$ & 71.0 & 24 & - & - & - & - \\
\hline Beak tip to centre of umbilicus & 145.0 & 50 & 175.0 & 48 & - & - \\
\hline Beak tip to genital slit (centre) & 178.0 & 61 & 220.0 & 61 & - & _- \\
\hline Beak tip to anus & 203.0 & 70 & 258.0 & 71 & - & - \\
\hline Beak tip to tip of dorsal fin & 202.0 & 69 & 249.0 & 69 & - & _ \\
\hline $\begin{array}{l}\text { Beak tip to anterior insertion } \\
\text { of dorsal fin }\end{array}$ & 182.0 & 63 & 224.0 & 62 & 385.0 & 65 \\
\hline $\begin{array}{l}\text { Beak tip to post. end of throat } \\
\text { creases }\end{array}$ & 39.0 & 13 & 48.0 & 13 & - & - \\
\hline Length of genital slit & 17.0 & 6 & 15.0 & 4 & - & - \\
\hline Length of mammary slits & 3.5 & 1 & - & - & - & - \\
\hline Length of anal opening & 8.0 & 3 & 10.0 & 3 & - & - \\
\hline Girth at axilla & 132.0 & 45 & - & - & - & - \\
\hline Maximum girth & 142.0 & 49 & - & - & $384.0^{\mathrm{b}}$ & 64 \\
\hline Girth at anus & 106.0 & 36 & - & - & - & - \\
\hline $\begin{array}{l}\text { Projection of lower jaw beyond } \\
\text { rostrum tip }\end{array}$ & 1.2 & 0 & - & - & - & - \\
\hline Length of eye opening & 2.7 & 1 & - & - & 5.0 & 1 \\
\hline $\begin{array}{l}\text { Centre of eye to angle of } \\
\text { mouth }\end{array}$ & 19.0 & 7 & - & - & - & - \\
\hline $\begin{array}{l}\text { Centre of eye to centre of } \\
\text { blowhole }\end{array}$ & $\begin{array}{l}27.0 / \\
23.0\end{array}$ & $8.6^{c}$ & - & - & - & - \\
\hline Blowhole width & 8.5 & 3 & - & - & - & - \\
\hline Length of throat grooves & 25.0 & 9 & 29.0 & 8 & - & - \\
\hline Flipper length, anterior & 29.0 & 10 & 26.0 & 7 & 55.0 & 9 \\
\hline Flipper length, posterior & 17.5 & 6 & 22.0 & 6 & - & - \\
\hline Flipper width, maximum & 8.0 & 3 & 9.0 & 2 & - & - \\
\hline Fluke width & 62.0 & 21 & 78.0 & 21 & - & _- \\
\hline Fluke depth & 20.5 & 7 & 22.0 & 6 & - & - \\
\hline Depth of fluke notch & NA & - & NA & - & - & _- \\
\hline Dorsal fin height & 13.0 & 4 & 18.0 & 5 & - & - \\
\hline Length dorsal fin base & 21.0 & 7 & 24.0 & 7 & - & - \\
\hline Weight & $228 \mathrm{~kg}$ & - & $510 \mathrm{~kg}$ & - & - & - \\
\hline
\end{tabular}

${ }^{\text {a }}$ Curvilinear length.

b Decomposition may have caused some bloating.

${ }^{c}$ Taken from mean of left and right hand measurements. 
highlighted the same features, particularly the patch of gray pigment extending antero-laterally across the upper part of the melon (Fig. 3I, arrow 5).

Much of the coloration of the Maldivian female was also lost through exposure to the sun. However, dark flecks and streaks were apparent on the pale ventral surface (Fig. 5C). Note that the detail in color pattern provided from the calves may not represent that of adults, as color patterns are known to change with age for some ziphiids (e.g., Mead 1989a, b).

Cranial osteology-Moore (1968) proposed the new genus Indopacetus for Longman's beaked whale based on four distinctive cranial features observed in the two skulls described from Queensland and Somalia (Longman 1926, Azzaroli 1968): (1) the frontal bones occupy an area of the vertex of the skull approximating or exceeding that occupied by the nasal bones; (2) there is minimal extension of the premaxillary crest on the vertex between the nasal and maxillary bones, or between the frontal and maxillary bones; (3) a deep groove about half the length of the orbit is present on the dorso-lateral margin of the maxillary bone above the orbit; and (4) as seen in dorsal view, the premaxillae retain an even width to about the midlength of the rostrum, where they may expand slightly before converging again towards the tip of the rostrum. This expansion differs from the changes that occur in the rostrum of adult male M. densirostris (e.g., Mead 1989a, fig. 15D), in which the maxillae narrow on each side for several centimeters anterior to the base of the rostrum, presenting a "pinched" appearance, before broadening again to its original breadth near the mid-length.

All four of these features were observed on the Kenyan skull (Fig. 6A-C, arrows) and confirm that this specimen represents Longman's beaked whale. Despite its youth, the skull of the juvenile, PEM1960, also displayed these features (Fig. 7). Features 1 and 2, relating to the comparative size and arrangement of bones on the vertex, were particularly clear (Fig. 7D), as was feature 3, the maxillary groove (Fig. 7C, arrow). At the time of writing, the Maldivian skull (Fig. 6D-F) was not sufficiently clean to examine suture details on the vertex. However, the anterior half of the rostrum narrowed slightly near the mid-length then widens again (Fig. 6D), similar to that observed in the other Indopacetus skulls.

The width of the rostrum at mid-length was due largely to the maxillary bones which form a broad, elongate flange along each side of the rostrum. In the holotype (Queensland), Somali, and Kenyan skulls, these bones formed an even concave curve from the cranium to the tip of the rostrum, as seen in lateral views (Fig. 6C, E; Fig. 7C). This arrangement may serve to strengthen the rostrum. The rostrum of Tasmacetus is very similar, both in its width for the proximal half of the rostrum and the curvature of the maxillary bones. However, in contrast to its width, the depth of the rostrum at mid-length was proportionately less in Indopacetus than in other ziphiids, as reflected by the ratio of rostrum width/depth at mid-length (Fig. 8).

The distinctive vertex of the Indopacetus skull is formed of the postero-dorsal portions of the left and right nasal and frontal bones, sandwiched between the dorsal rim of the supraoccipital bone posteriorly, the maxillary bones laterally, the left and right nasal bones anteriorly, and the premaxillary crests antero-laterally (e.g., Fig. 7D). The nasal and frontal bones are irregular in shape. The nasals protrude anteriorly between the maxillary crests, extending farthest along the suture line that separates them. However, they do not protrude anteriorly beyond the line connecting the anterior faces of the maxillary crests (Fig. 6A, D; 7D).

The form of the vertex in Indopacetus contrasts with that of other ziphiid genera (Fig. 9): in Berardius and Tasmacetus, the nasal bones occupy an area on the vertex far 
exceeding that of the frontals and premaxillae; in Ziphius, the nasals are also enlarged and protrude anteriorly to overhang the external bony nares; in Mesoplodon, the cranial vertex is extremely well developed (Mead 1989a) with prominent premaxillary crests; and, in Hyperoodon, the cranial vertex is developed to a similar extent as that in Mesoplodon spp. (Moore 1968). Hyperoodon spp. are further distinguished from other genera by the prominent development of their maxillary crests (e.g., Mead 1989b, fig. 2). While a detailed comparison of vertex structure among ziphiids (including the potential use of these features to infer evolutionary relationships) is outside the scope of this paper, the distinctiveness of Indopacetus from Mesoplodon spp. (and also Hyperoodon spp.) is nonetheless apparent (Fig. 9).

The nasal and frontal bones on the vertex show different degrees of fusion in the three Indopacetus skulls in which suture details can be observed, presumably as a reflection of age. Those of the South African (PEM1960) specimen were not fused and easily distinguishable, those in the holotype were far less discernible, and those of the Kenyan skull were almost obliterated. There was very little difference, other than size, in the shape and relative placement of the nasals and frontal bones in the skulls of the adults and juvenile (Fig. 6,7).

Comparison of cranial measurements (Table 3) suggested that the Kenyan and Somali skulls were very similar in overall structure to the holotype. ${ }^{3}$ However the Maldivian skull was consistently and distinctly narrower than those of the other three adults in a range of measurements: breadth of the cranium (Table 3, measurements 17-20); width of the premaxillae along their entire length and the width of the rostrum at mid-length (Table 3, measurements 29, 32-35). The least distance between the premaxillary foramina was also smaller in this specimen. It is possible that these differences reflect sexual dimorphism, as has been observed in other ziphiid species (e.g., Heyning 1989; Mead 1989a, b). Alternatively, this may be due to slight differences in techniques of skull measurement by different researchers.

Other features of the skull described previously for the holotype and Somali skulls (Moore 1972) were also apparent in the Kenyan skull and that of the juvenile, PEM1960. The lacrimal bone was large and hood-shaped, and was the primary contributor to the antorbital tubercle (e.g., Fig. 6C). This feature also differentiates Indopacetus from Mesoplodon spp. (Mead 1989a). In PEM1960, the Kenyan and Maldivian skulls, mesorostral ossification was minimal. In the latter specimen (adult female) the mesorostral ossification rose above the rim of the mesorostral canal immediately anterior to the nares but was restricted to the posterior portion of the mesorostral canal. A similar situation was observed in the holotype and Somali specimens. In adult males of Mesoplodon spp. the mesorostral canal is usually filled in through proliferation of the vomer (Mead $1989 a)$.

Teeth and dentition-Three of the specimens described in this paper provide the first opportunity to examine the teeth of Indopacetus. The dentition comprised a single pair of teeth which are set close to the tip of the jaw (Fig. 7E, 10). The teeth were very similar in shape to that predicted by Mead $(1989 a)$.

The teeth of the neonate, PEM292, were fully enclosed in the terminal alveoli (tooth sockets). They lay $3-4 \mathrm{~mm}$ from the tip of the mandible and were angled

\footnotetext{
${ }^{3}$ Other than several longitudinal measurements of the Somalian skull which include the rostrum and appear inconsistent in proportion, reflecting the difficulty of estimating corrections for damage.
} 

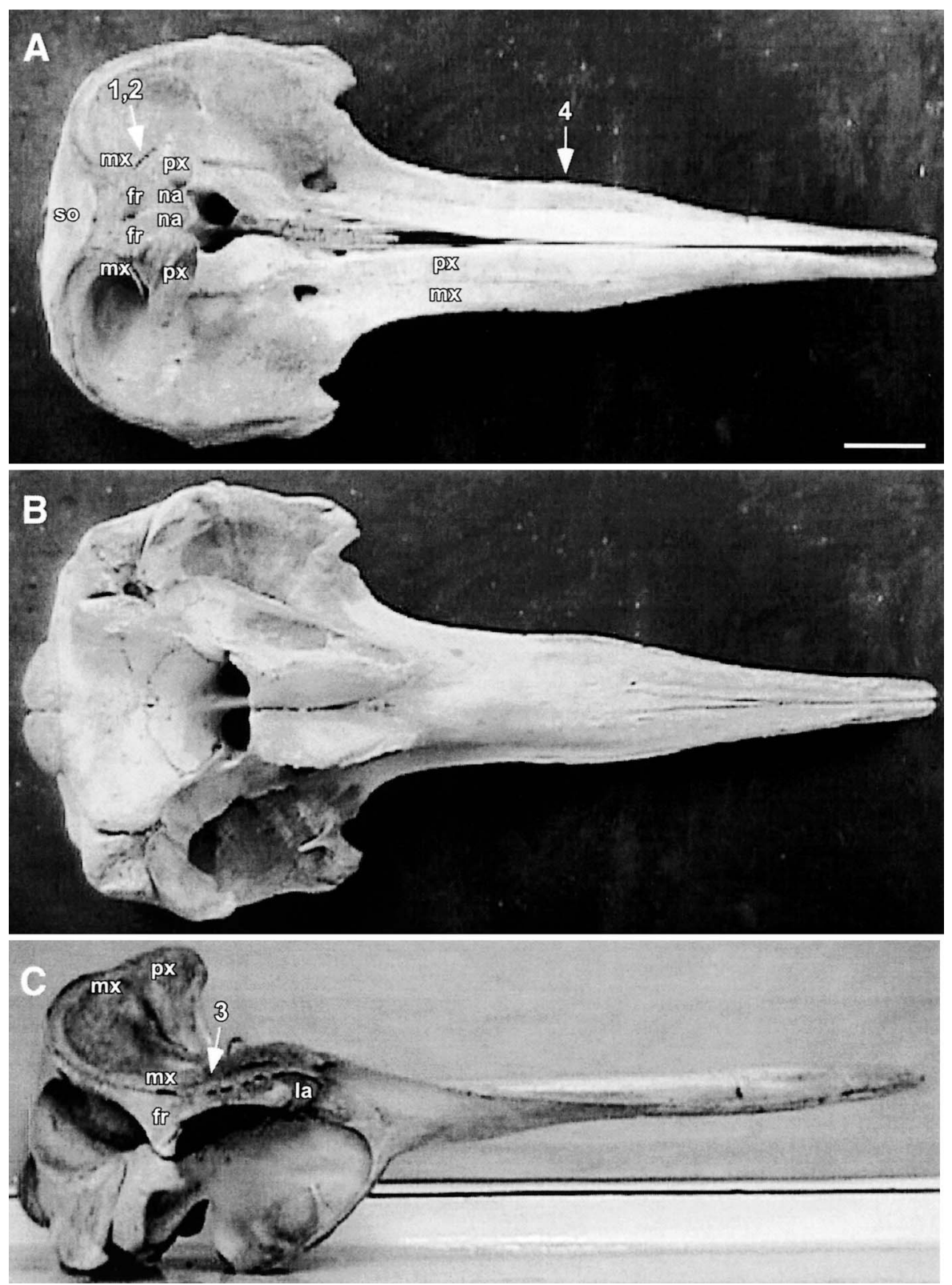

Figure 6. Skulls of mature Longman's beaked whales; OM7622, Kenya: (A) dorsal view; (B) ventral view; (C) lateral view (scale bar $=10 \mathrm{~cm}$, images A-C). Republic of Maldives: (D) dorsal view; (E) ventral view; (F) lateral view (scale bar $=30 \mathrm{~cm}$, images D-F). Arrows (numbered as in text) highlight diagnostic cranial features discussed by Moore (1968). fr, frontal; la, lacrimal; na, nasal; mx, maxilla; px, premaxilla; so, supraoccipital. Photocredits: (A-C) H. L. Hinsz, (D-H) R. C. Anderson. 

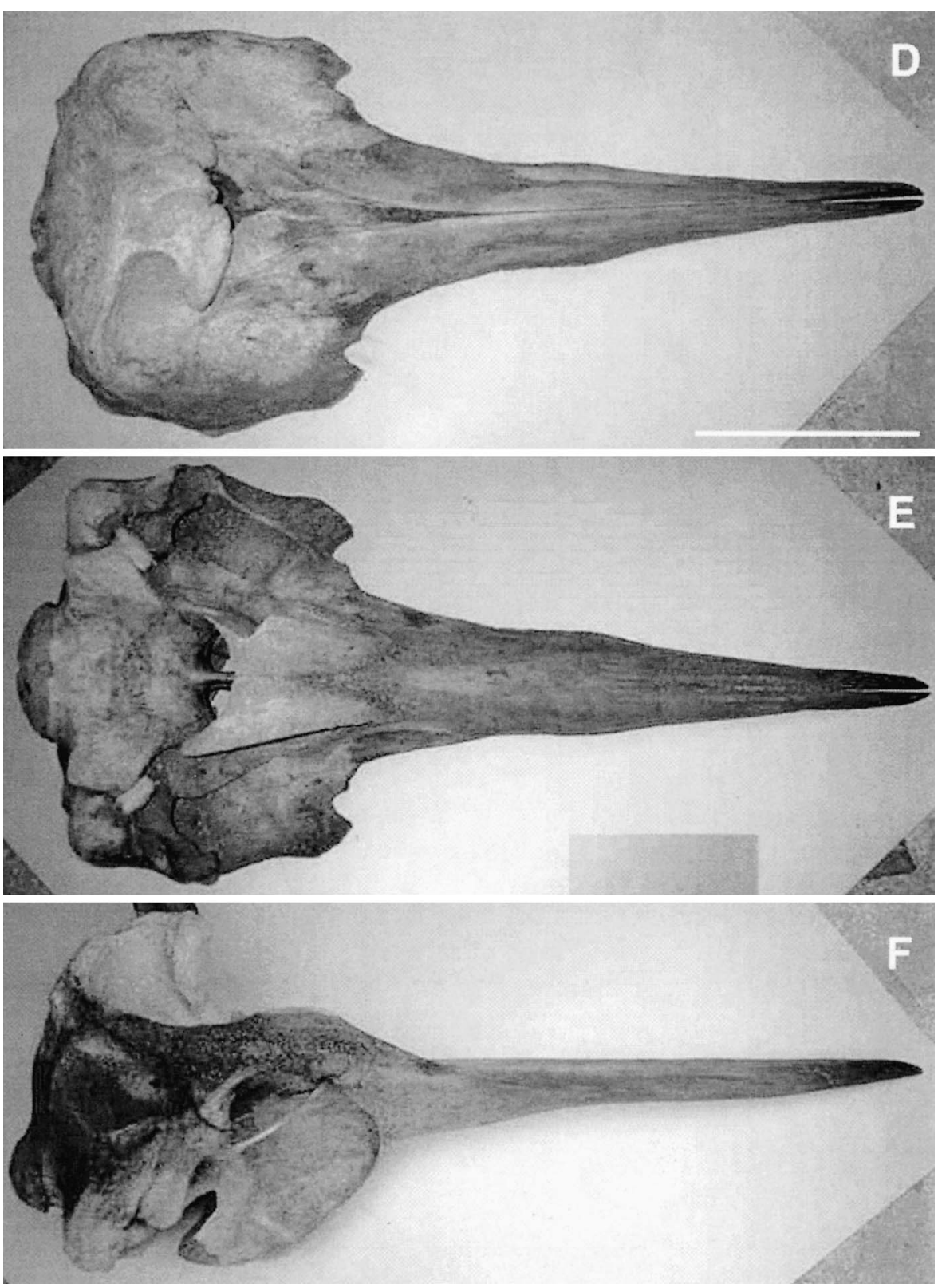

Figure 6. Continued.

forward at about $45^{\circ}$ (Fig. 10E, X-ray of beak). In lateral view each tooth appeared as a hollow, evenly tapered cone, $20 \mathrm{~mm}$ in length and $11.5 \mathrm{~mm}$ in diameter at the base. The prenatal dentine was $\sim 1 \mathrm{~mm}$ at its thickest part, near the apex of the pulp cavity. The teeth of the juvenile, PEM1960 (Fig. 7E) were similar in form; 

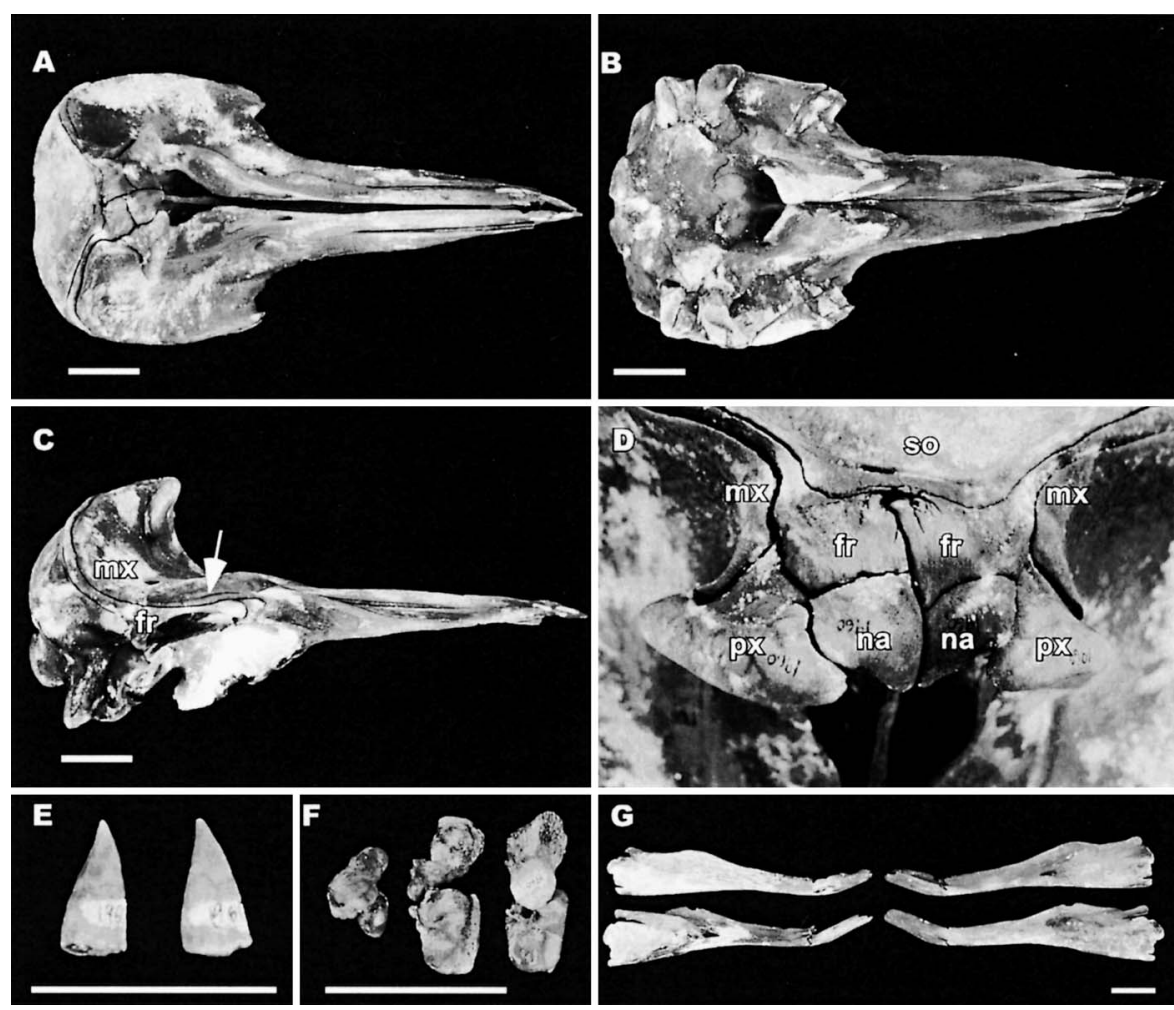

Figure 7. Skull, teeth and earbones of juvenile Longman's beaked whale; PEM1960: (A) dorsal view of skull; (B) ventral view of skull; (C) lateral view of skull; (D) close-up of cranial vertex; (E) lateral view of teeth; $(\mathrm{F})$ periotic and tympanic bones; $(\mathrm{G})$ lateral view of exterior and interior of mandibular rami. Arrow highlights the position of the maxillary groove (Moore 1968). fr, frontal; na, nasal; mx, maxilla; px, premaxilla; so, supraoccipital. Scale bars for all images except $\mathrm{E}=10 \mathrm{~cm}$. Scale bar for image $\mathrm{E}=5 \mathrm{~cm}$. Photocredit: P. B. Best.

slightly longer $(27 \mathrm{~mm})$ but a similar width at the base $(\sim 11 \mathrm{~mm} \times 13 \mathrm{~mm})$. Mandibular measurements are provided in Table 4.

The teeth of the adult female were also roughly conical in shape (Fig. 10B). In situ a small portion of the teeth protruded from the alveoli (Fig. 10A; note that the teeth have likely fallen slightly forwards out of the alveoli as the jaw was raised up to vertical for this photograph). However, in life this emergent portion was apparently covered by thick gum tissue such that the teeth were not visible (Fig. $5 \mathrm{~A}$, arrow 2), nor could they be detected through gentle palpation post mortem. Among all beaked whales (except Berardius spp.), only mature males have erupted teeth. (In Tasmacetus, both sexes have a full complement of teeth, but the larger apical pair erupt only in adult males; Mead 1989c). From these observations we assume that Indopacetus follows the same pattern.

The teeth of the adult female were oval in cross-section at the base due to slight lateral (transverse) flattening (Fig. 10C). A thick cementum sheath covered the entire base of both teeth to a thickness of $\sim 2-4 \mathrm{~mm}$ (Fig. 10B). There was no evidence that this sheath was pathological, and it is likely that this is the normal 


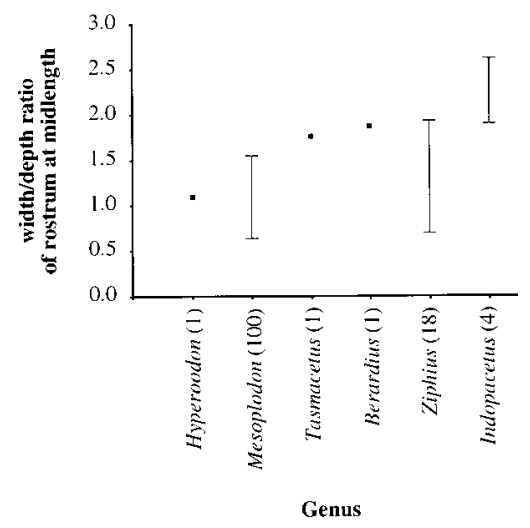

Figure 8. Width/depth ratio of rostrum at mid-length for all ziphiid genera. Number of specimens examined for each genus shown in brackets. Figures derived from the specimens described in this paper, unpublished data from G. J. B. Ross, and the following sources: Azzaroli (1968), Dixon (1970), Kasuya and Nishiwaki (1971), McCann (1962a,b), McCann and Talbot (1963), Miyasaki et al. (1987), Moore (1963), Nishiwaki and Kamiya (1958), Oliver (1937), Omura (1972), Reyes et al. (1991), Ross (1984), Ross and Teitz (1972), Scott and Lord (1920), and Zerbini and Secchi (2001).

condition for the species. A similar cementum sheath has been observed on the teeth of many female Mesoplodon beaked whales and some female Ziphius. ${ }^{4}$ Most Mesoplodon spp. have teeth composed of tightly packed layers of dentine covered in a thin external layer of cementum which extends up from the root. Only in adult males with hypertrophied teeth does tooth growth continue through substantial deposition of cementum (Perrin and Myrick 1980). The left tooth of the Maldivian female bore a circular cavity, $\sim 6 \mathrm{~mm}$ in diameter and $4-5 \mathrm{~mm}$ deep, on its medial surface through which the internal osteodentine was visible. This cavity is thought to be a resorption lesion resulting from a tooth abscess. This would fit with the clinical description of the tooth crown being covered by soft tissue. ${ }^{5}$ There was no visible wear on the teeth. A large part of the pulp cavity of the tooth of the adult female was still open (Fig. 10C, D), forming a hollow conical space, $\sim 10 \mathrm{~mm}$ in diameter and $\sim 13 \mathrm{~mm}$ in depth. A number of nodules were visible on the walls of the pulp cavity, and are thought to be pulp stones or secondary centers of dentine deposition. Assuming the size of the teeth in PEM292 is typical for neonate Indopacetus, the tooth of the adult female has almost doubled in length since birth.

Beaked whales of the genera Hyperoodon, Tasmacetus, and Ziphius have comparatively simple conelike teeth set at the apex of the lower jaw (e.g., Moore 1968), similar to those now observed in at least adult female Indopacetus. Apical, conelike teeth are likely to represent the ancestral form among ziphiids (Moore 1968). In Mesoplodon beaked whales the teeth are generally derived and specialized (e.g., Mead 1989a). Only three species of Mesoplodon have apical teeth (M. hectori, M.

\footnotetext{
${ }^{4}$ Personal communication from J. G. Mead, Smithsonian National Museum of Natural History, Washington, DC, e-mail, 4 October 2001.

${ }^{5}$ Personal communication from F. Verstraete, Department of Radiological and Surgical Sciences, School of Veterinary Medicine, University of California, Davis, CA, e-mail, 12 June 2001.
} 


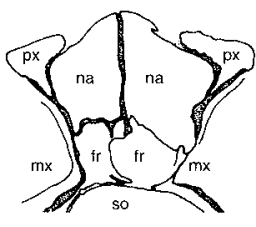

Berardius amuxii

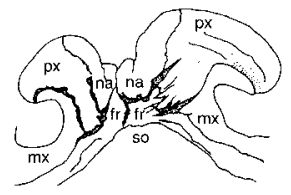

Hyperoodon planitrons

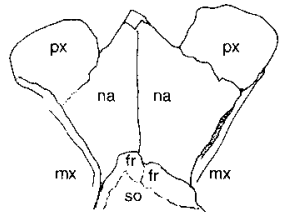

Tasmacetus shepherdi

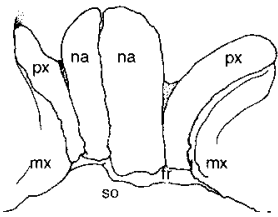

Ziphius cavirostris
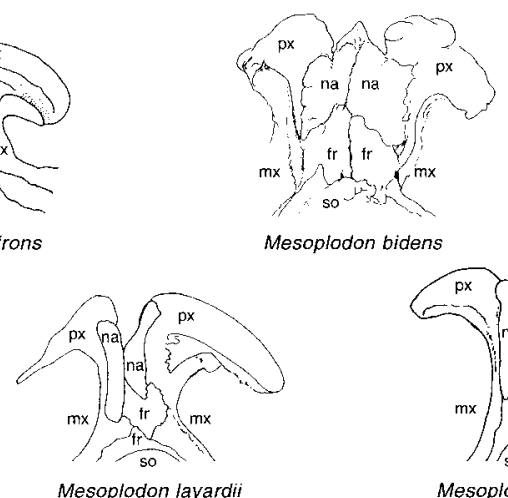

Mesoplodon bidens
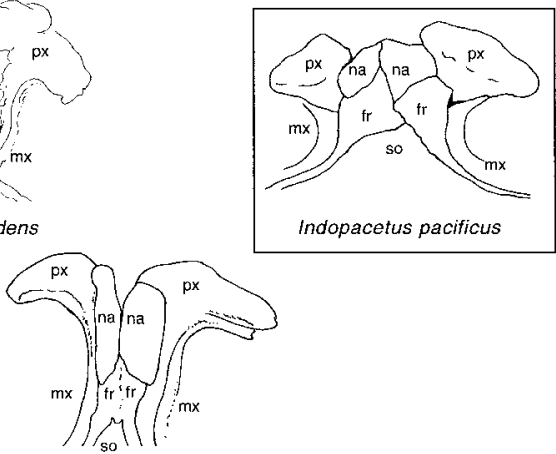

Mesoplodon mirus

Figure 9. The form in the dorsal surface of the vertex varies considerably within and between the six extant ziphiid genera. The three Mesoplodon spp. shown reflect the range of morphology in this genus: the type species of the genus, M. bidens (USNM504146, Mead 1989a); M. layardii (RNP 326, Goodall 1978); and M. mirus (SAM 33295, McCann and Talbot 1963). Information and sources for the other genera are: Berardius arnuxii (DM 183, Moore 1968); Hyperoodon planifrons (FMNH 15553, Moore 1968); Tasmacetus shepherdi (UCM 1063, Moore 1968); Indopacetus pacificus (M4854, Azzaroli 1968) and Ziphius cavirostris (FMNH 99362, Moore 1968). fr, frontal; mx, maxillary; na, nasal; px, premaxillary; so, supraoccipital.

mirus, and M. perrini). In other Mesoplodon spp. the single pair of teeth is set back from the apex of the jaw. Mesoplodon teeth are also laterally flattened, a feature thought to distinguish this genus from all others except Berardius (Moore 1968). However, the teeth of the recently described species, $M$. peruvianus, are more oval in cross-section (Reyes et al. 1991) and, together with those of M. mirus, are similar in form to those of Ziphius. So while tooth form in most Mesoplodon spp. is derived, some have still retained simple conelike teeth.

The alveoli of Indopacetus are shallow compared to those of Mesoplodon spp., especially males. Moore interpreted the holotype as representing an "old adult male [in which the alveoli] become progressively at least as shallow as $30 \mathrm{~mm}$ " (Moore 1968 , p. 282). In contrast, the alveoli of aging Mesoplodon males remain deep, often containing more than half the length of the tooth, and probably exceed $30 \mathrm{~mm}$ in depth (Moore 1968). The alveoli of the holotype and Maldivian adult female were very similar in length and width (Table 4, measurements 9 and 10), suggesting that the teeth they supported were also similar in form and size. Moore's (1968) suggestion that alveolus depth is diagnostic for this species should therefore be reevaluated to include both sexes. Alternatively, it is possible that the holotype does not represent an adult male. 
Postcranial osteology - The vertebral count of PEM292 was C7 T10 L12 Cd7 + = $36+$. Most of the caudal vertebrae remaining in the frozen tailstock of this specimen were lost in storage prior to preparation. The first five cervical vertebrae were fused. The anterior seven pairs of ribs were double-headed. The tubercle of the seventh rib articulated with the superior transverse process. On the eighth thoracic vertebra, there was an abrupt replacement of the superior transverse process by an inferior transverse process. Very little skeletal material was retrieved from PEM1960. However, there were ten intact ribs on one side, of which the first seven were double-headed. The vertebral count of the Maldivian adult female was $\mathrm{C} 7 \mathrm{~T} 10 \mathrm{~L} 9 \mathrm{Cd} 15+=41+$. A small number of caudal vertebrae were lost in preparation. The anterior seven pairs of ribs were double-headed and the last three had a single articulation. The first five cervical vertebrae were fused, although the fifth vertebra was only partly attached. The sixth and seventh cervicals were quite separate. Each epiphysis was fused to its respective vertebral body. The larger number of lumbar vertebrae in PEM292 probably reflects the young age of this specimen and the consequent difficulty in detecting the position of the first chevron bone. Based on examination of these specimens, I. pacificus appears to have ten pairs of ribs, although it is recognized that sample size is very small. No information is available regarding phalangeal formula.

\section{Natural History}

Ontogeny and reproduction - The testes of the smallest animal (PEM292; $291 \mathrm{~cm}$ TL) measured $41 \times 14 \mathrm{~mm}$ and $40 \times 15 \mathrm{~mm}$ and weighed $3.7 \mathrm{~g}$ and $3.2 \mathrm{~g}$, respectively. Histological sections through the center of the testis showed abundant interstitial tissue and narrow tubules with a reduced or no lumen. The mean tubule diameter at the center and periphery of the testis at mid-length was $35 \mu$ (Ross 1984).

In PEM292 the margins of the tongue were fimbriated, especially on the lateral edges, presumed to be related to suckling. The umbilicus appeared to be completely healed. However, on the right hand side of the body, at least six narrow, vertical, dark fetal folds were visible. Based on information from bottlenose dolphins Tursiops sp., where such fetal folds remain visible for up to a month after birth, it is likely that this animal was not more than a few weeks old (Ross 1984). As PEM292 stranded in early November, it was probably born in late September or October. The second juvenile, PEM1960, stranded in early August. Assuming that the length of PEM292 was close to the birth length in this species, PEM1960 $(363 \mathrm{~cm}$ TL) may have been born during the previous season, and as such would be approximately eight to ten months old. No fetal folds were visible on this specimen. The Maldivian adult female, which stranded in mid-January, carried a fetus, which was $104 \mathrm{~cm}$ in length. No other measurements were taken of the fetus due to extensive decomposition.

Scarring and bite marks_-A fresh cookie-cutter shark bite (Isistius sp.; Jones 1971) was present on the right side of the calf, PEM292, just above the flipper (Fig. 3A, B). A set of tooth rakes, probably caused by a large shark, was present on the ventral-left lateral surface of the body, near the caudal peduncle (Fig. 3B). There were no obvious scars on PEM1960. Fresh bites were noted on the flukes and dorsal fin of the Maldivian specimen, probably caused by large sharks while the animal was dead and drifting with the currents. Linear tooth rake scars potentially inflicted by conspecifics (e.g., Heyning 1984) were not observed on any of the animals examined. 


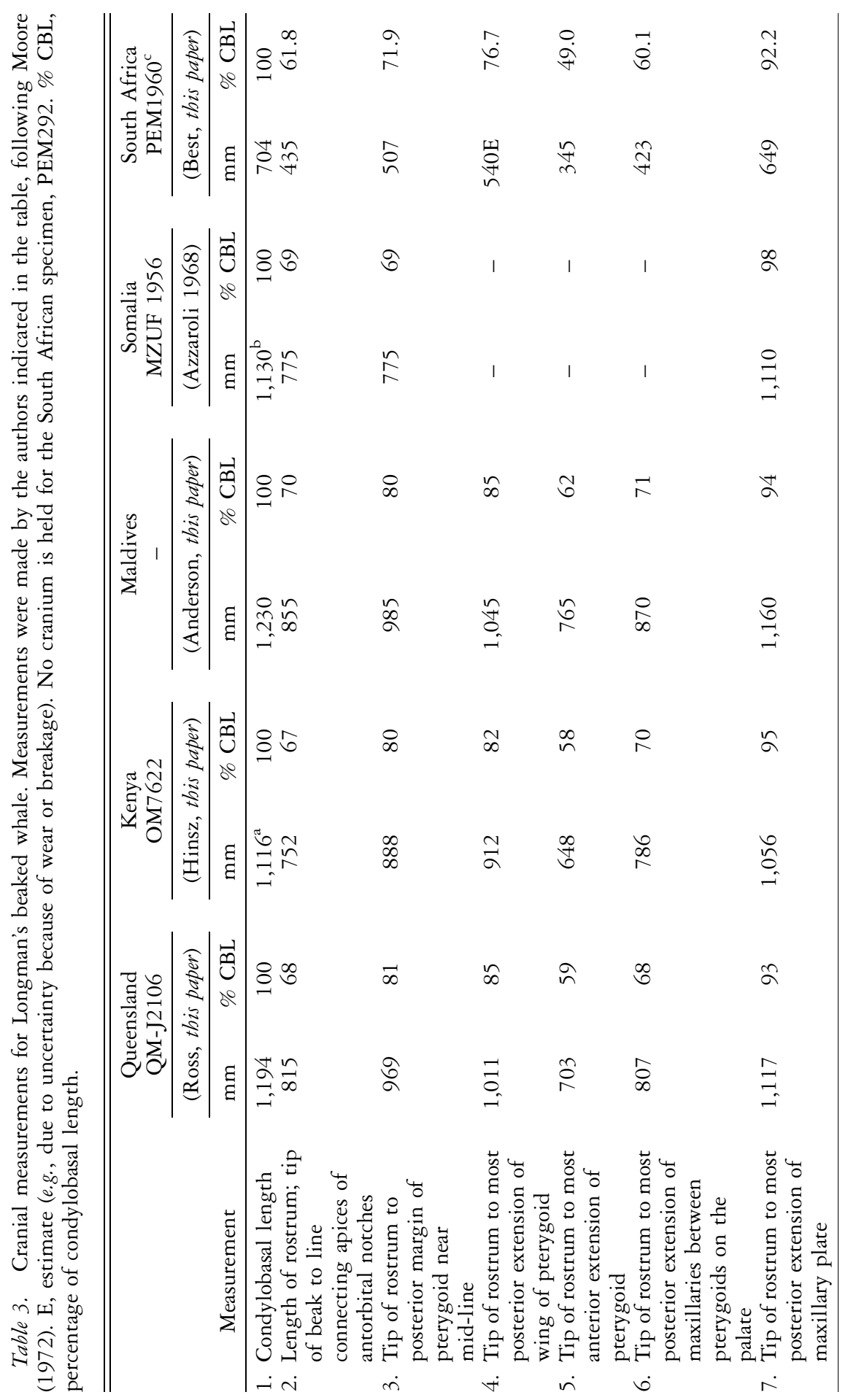




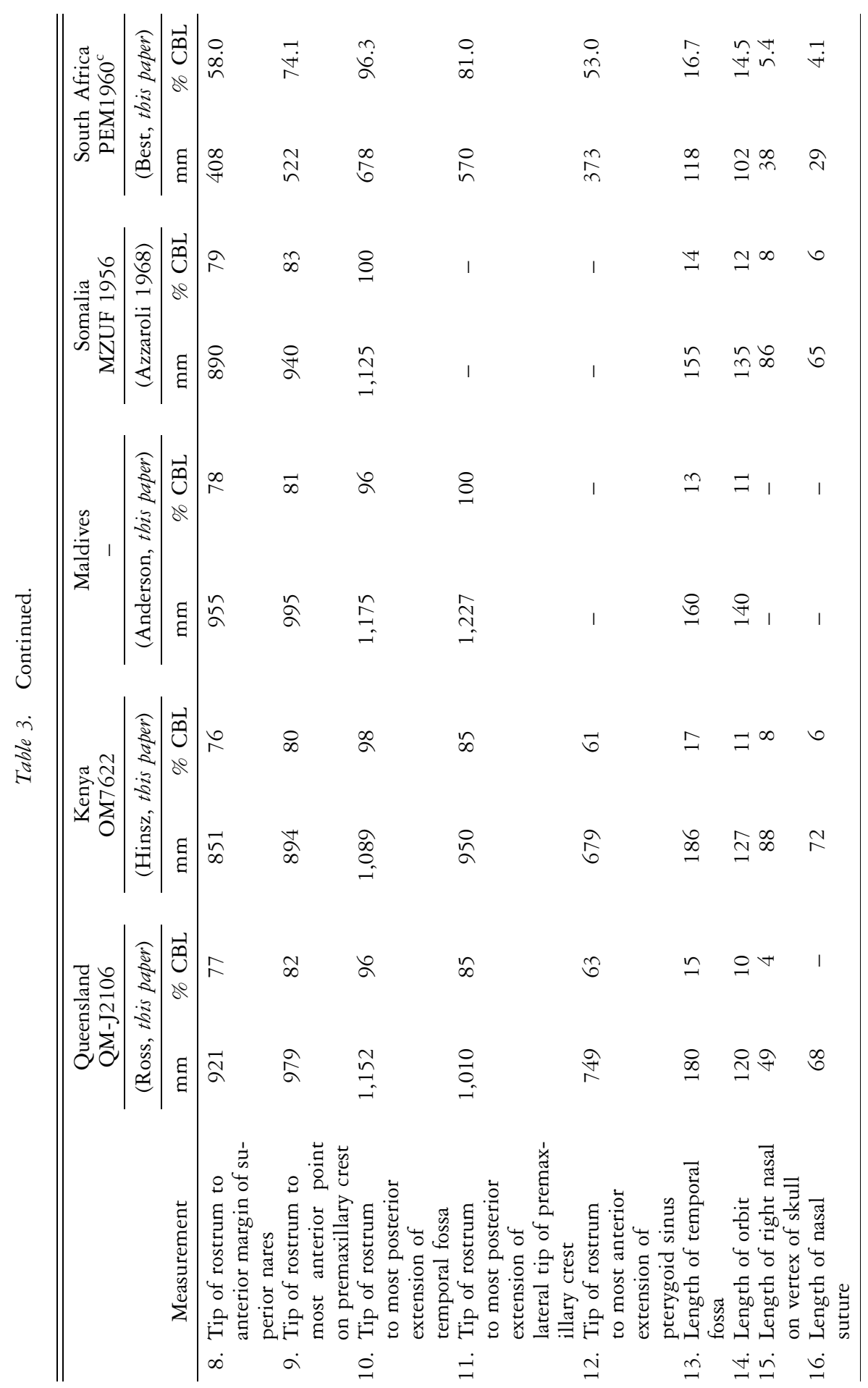


446

MARINE MAMMAL SCIENCE, VOL. 19, NO. 3, 2003

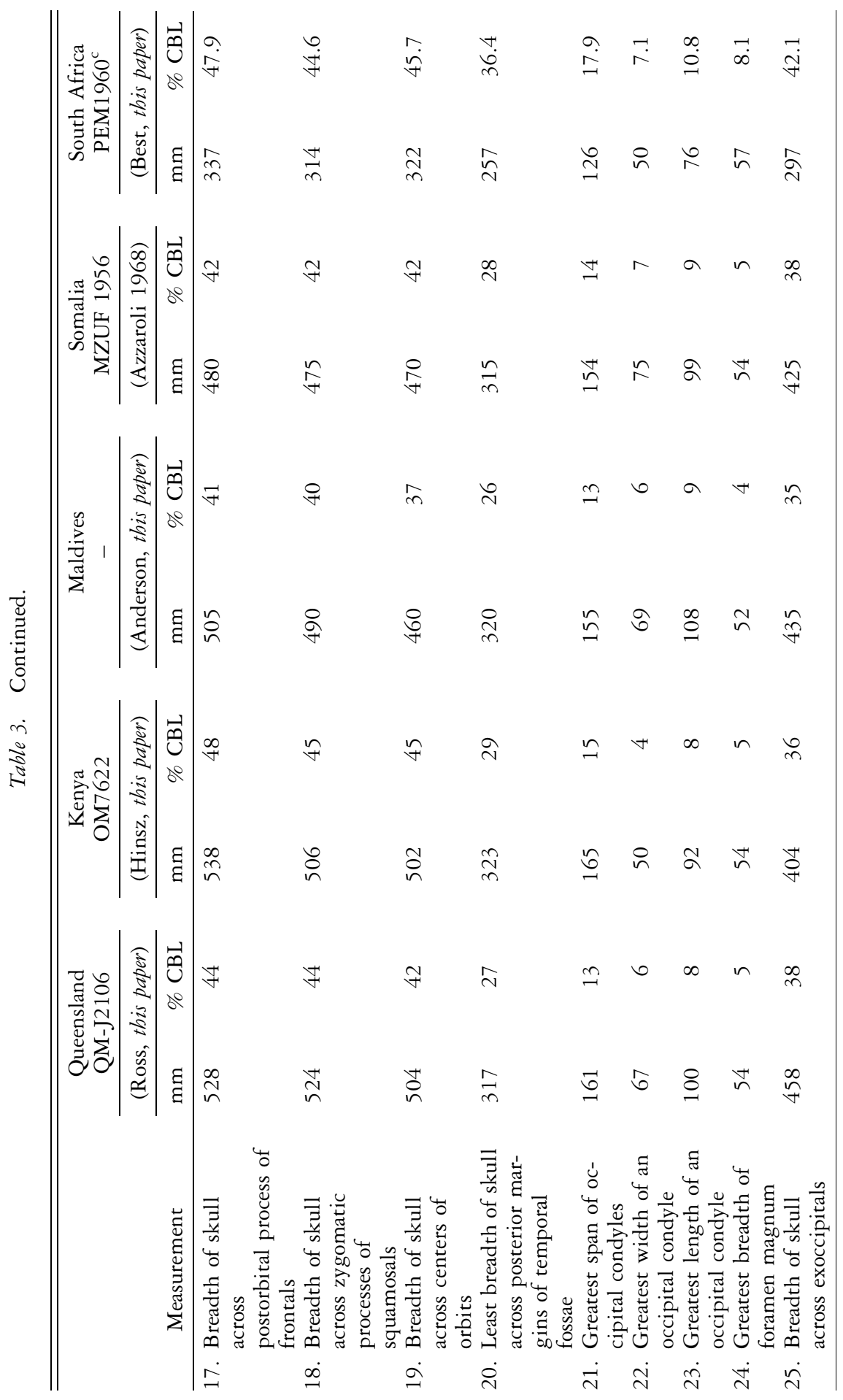




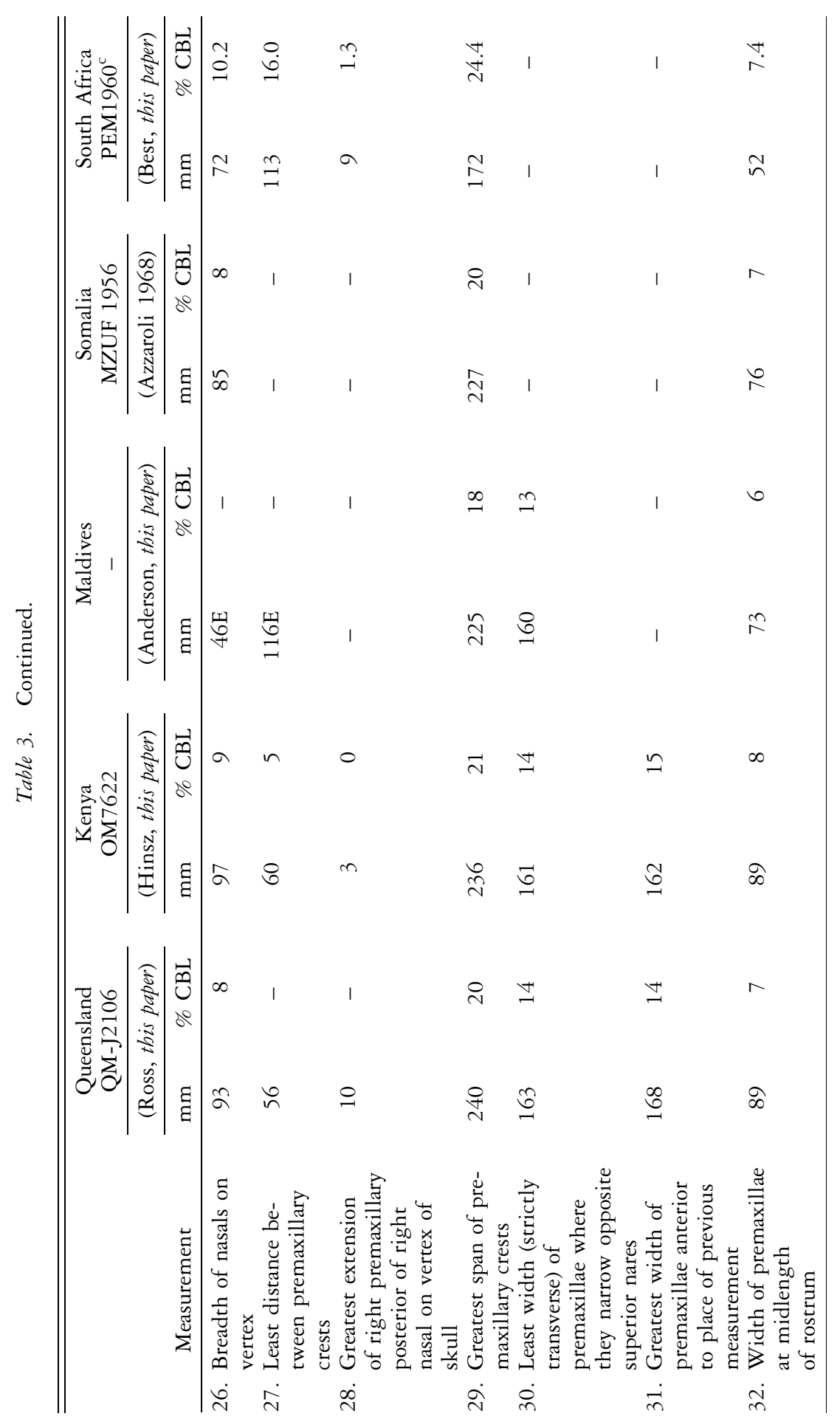


448

MARINE MAMMAL SCIENCE, VOL. 19, NO. 3, 2003

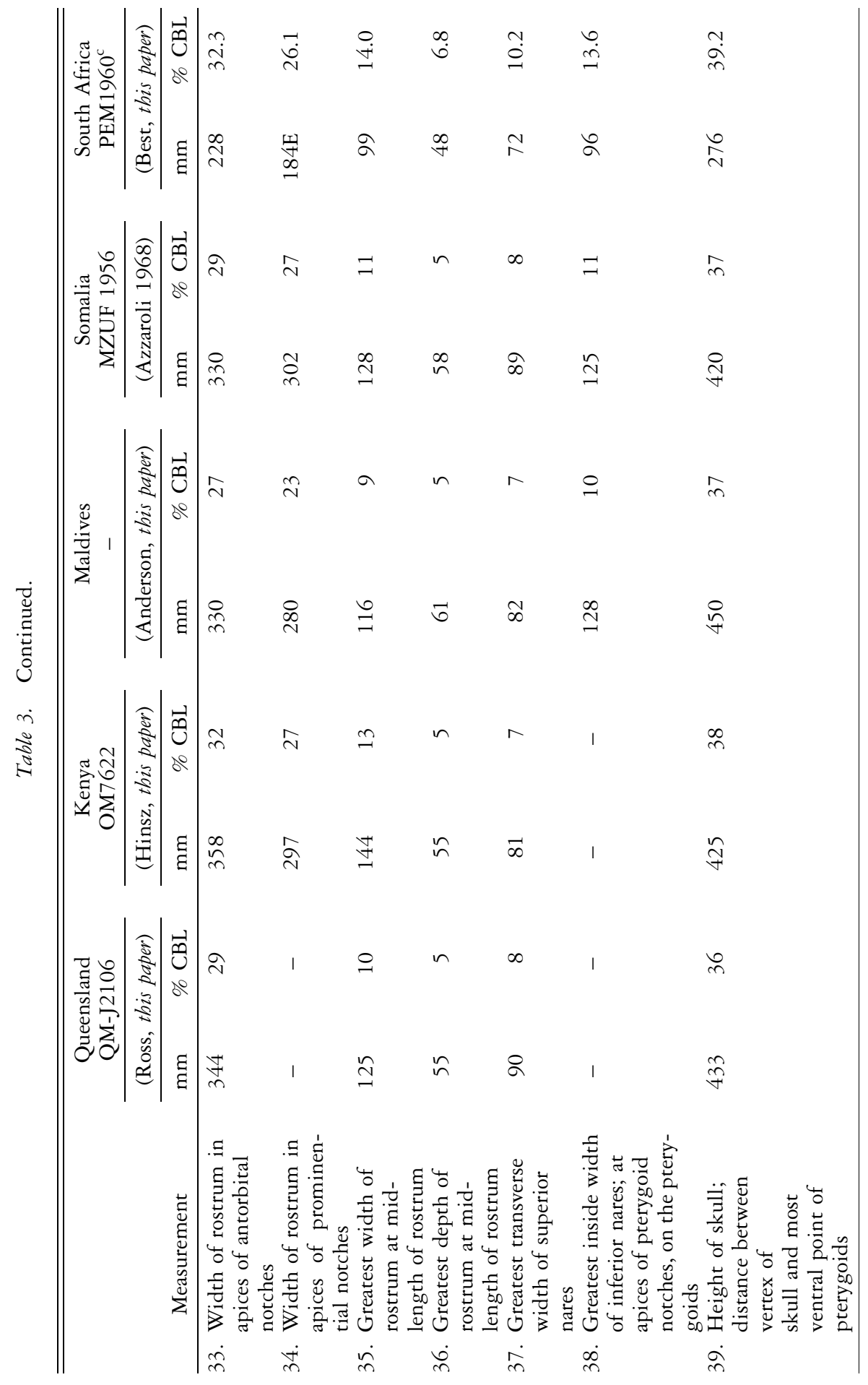




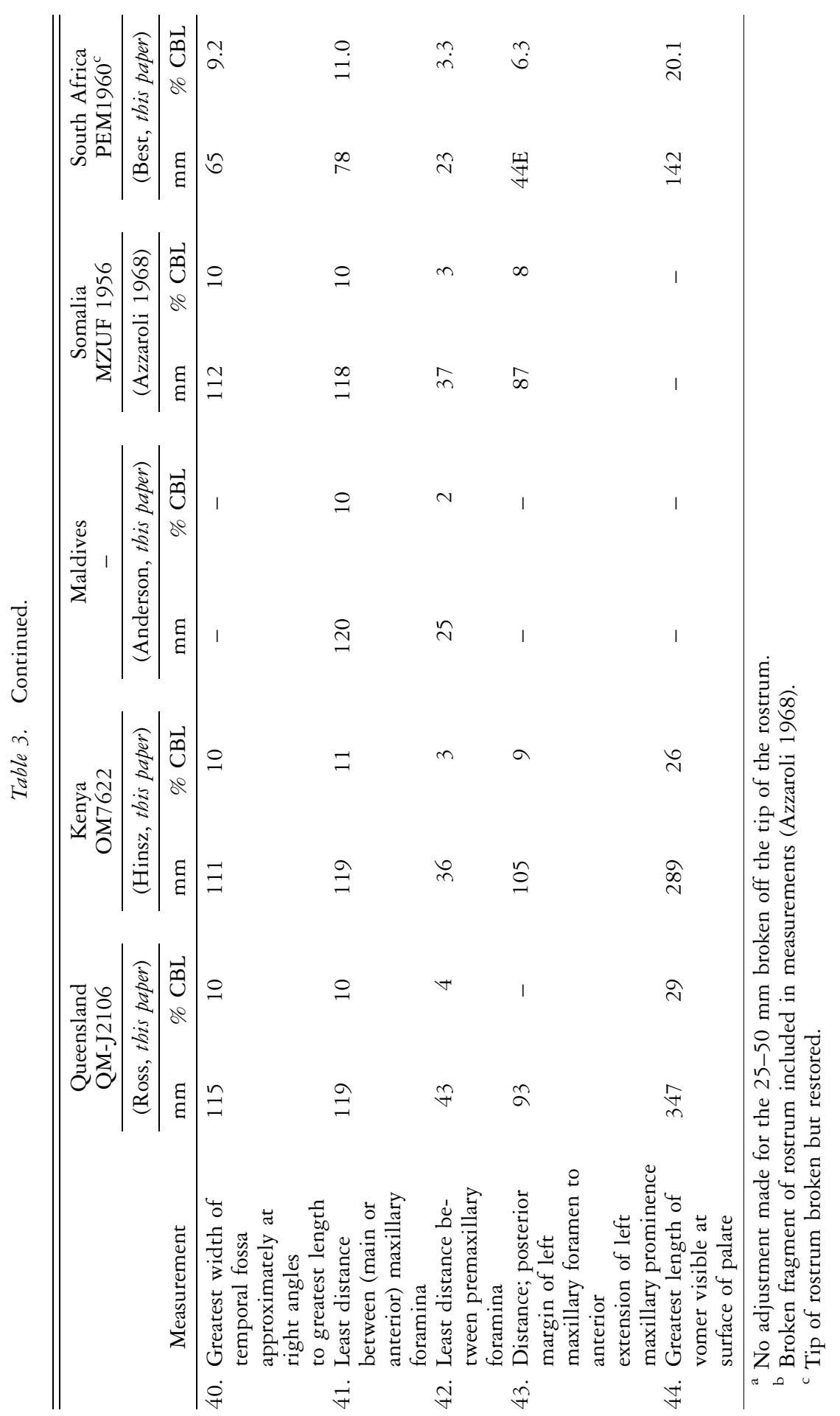




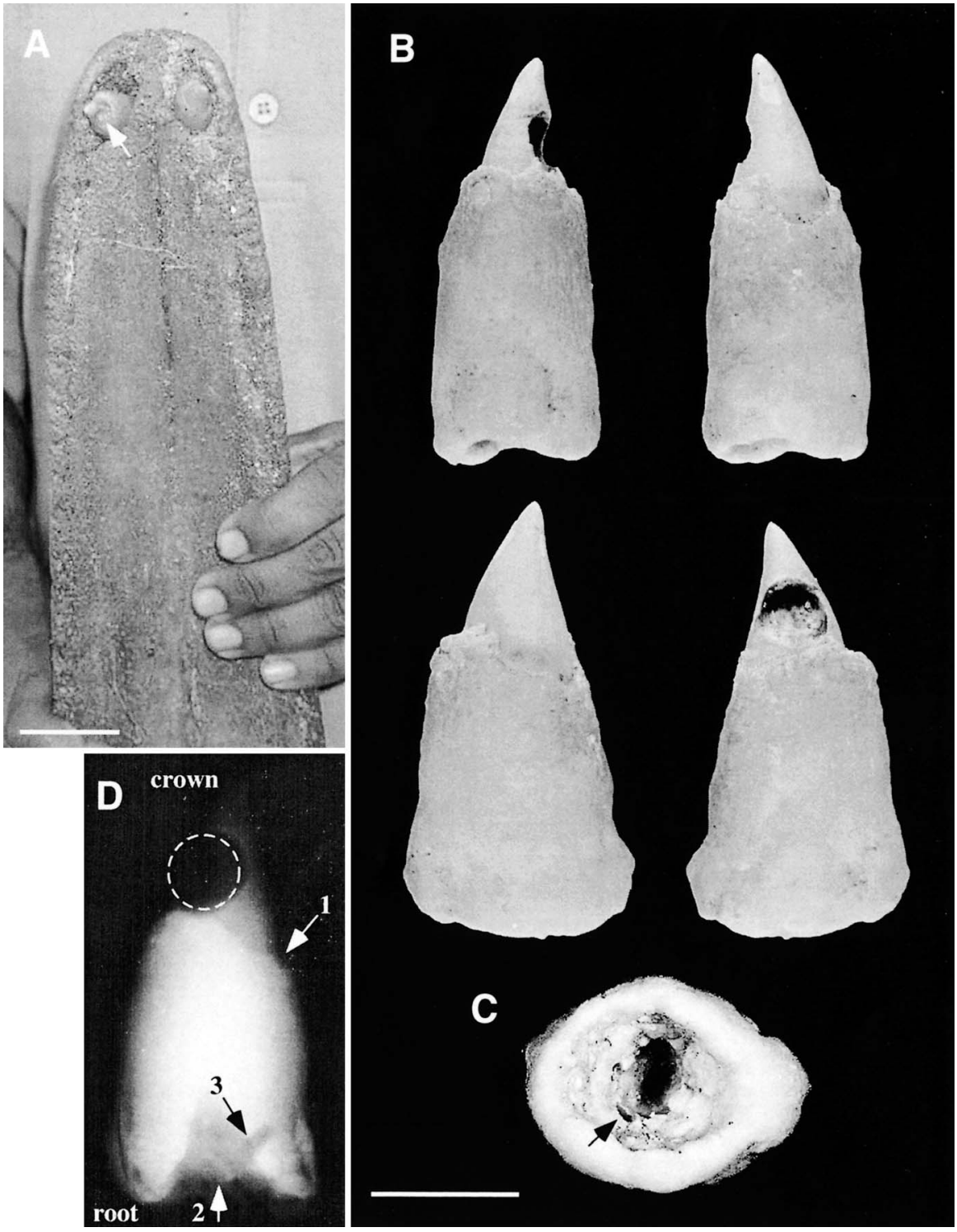

Figure 10. Teeth of Longman's beaked whales; adult female, Republic of Maldives: (A) dorsal view of mandible with teeth in situ arrow indicates position of cavity in left tooth (scale bar $=5 \mathrm{~cm}$ ); (B) anterior, posterior, distal, and medial view of left tooth; (C) looking up into pulp cavity of left tooth arrow indicates position of drill hole resulting from DNA extraction procedure; (D) X-ray of left tooth. Arrow 1, cementum sheath; arrow 2, angle from which photo in $\mathrm{C}$ was taken; arrow 3, position of drill hole; dashed circle, position of cavity. Scale bar (images B-D) $=1 \mathrm{~cm}$. (E) X-ray of beak of neonate, PEM292, in lateral view (scale bar $=2 \mathrm{~cm}$ ). Photocredits: (A), R. C. Anderson; (B) and (C), I. MacDonald. 


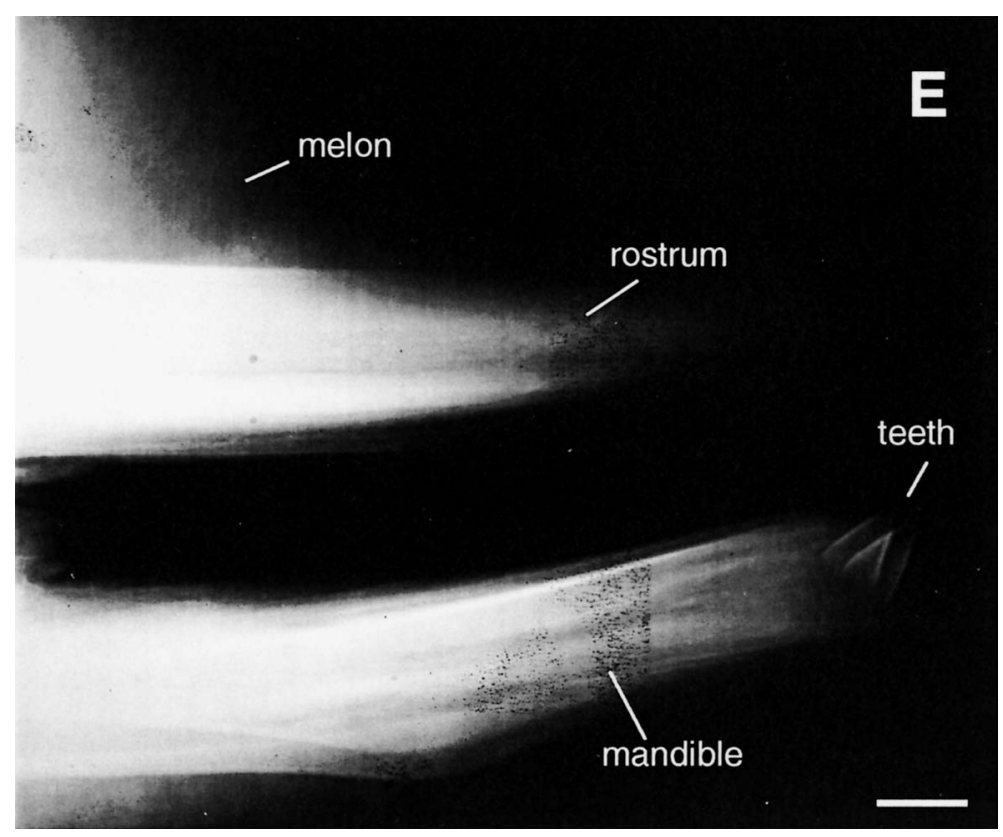

Figure 10. Continued.

Pollutant loads - Cockcroft et al. (1991) presented information on organochlorine pesticide loads for the South Africa neonate, PEM292. The blubber of this animal contained $1.2 \mathrm{ppm}$ DDE, $0.4 \mathrm{ppm}$ TDE, $2.99 \mathrm{ppm}$ DDT, $0.07 \mathrm{ppm}$ Dieldrin, and t-DDT $^{\prime} 1.6 \mathrm{ppm}$, with a DDE/t-DDT ${ }^{\prime}$ ratio of 0.75 . There were no detectable levels of PCBs. Given the young age of this animal, these pollutants would have been received through its mother's milk.

\section{DisCUSSION}

Longman's beaked whale is now known from a total of six specimens, from the western reaches of the tropical Pacific Ocean $\left(21^{\circ} 10^{\prime} \mathrm{S}, 149^{\circ} 10^{\prime} \mathrm{E}\right)$, and the western, northern, and southern latitudes of the tropical Indian Ocean (range, $3^{\circ} 26^{\prime} \mathrm{N}$, $73^{\circ} 26^{\prime} \mathrm{E}$ to $29^{\circ} 39^{\prime} \mathrm{S}, 31^{\circ} 36^{\prime} \mathrm{E}$ ). The discovery of the South African animals has extended the known distribution in the Indian Ocean by more than $30^{\circ}$ of latitude and suggests that this species may be parapatric with $H$. planifrons in the southern part of its range (Mead 1989b). Sightings in the tropical Indian and Pacific Oceans that have been attributed to I. pacificus (i.e., animals identified as "tropical bottlenose whales" or "bottlenose-like" in appearance [Hyperoodon sp. or $H$. planifrons]) are listed in table 1 of Pitman et al. (1999). These sightings are distributed throughout tropical Indo-Pacific waters from Mörzer Bruyns' (1971) observations in the Arabian Sea to those of Gallo-Reynoso and Figueroa-Carranza (1995) around Isla da Guadalupe, Mexico.

The distinctive color patterning of the newly identified Indopacetus calves was compared to that of calves of these unidentified bottlenose whales observed and 


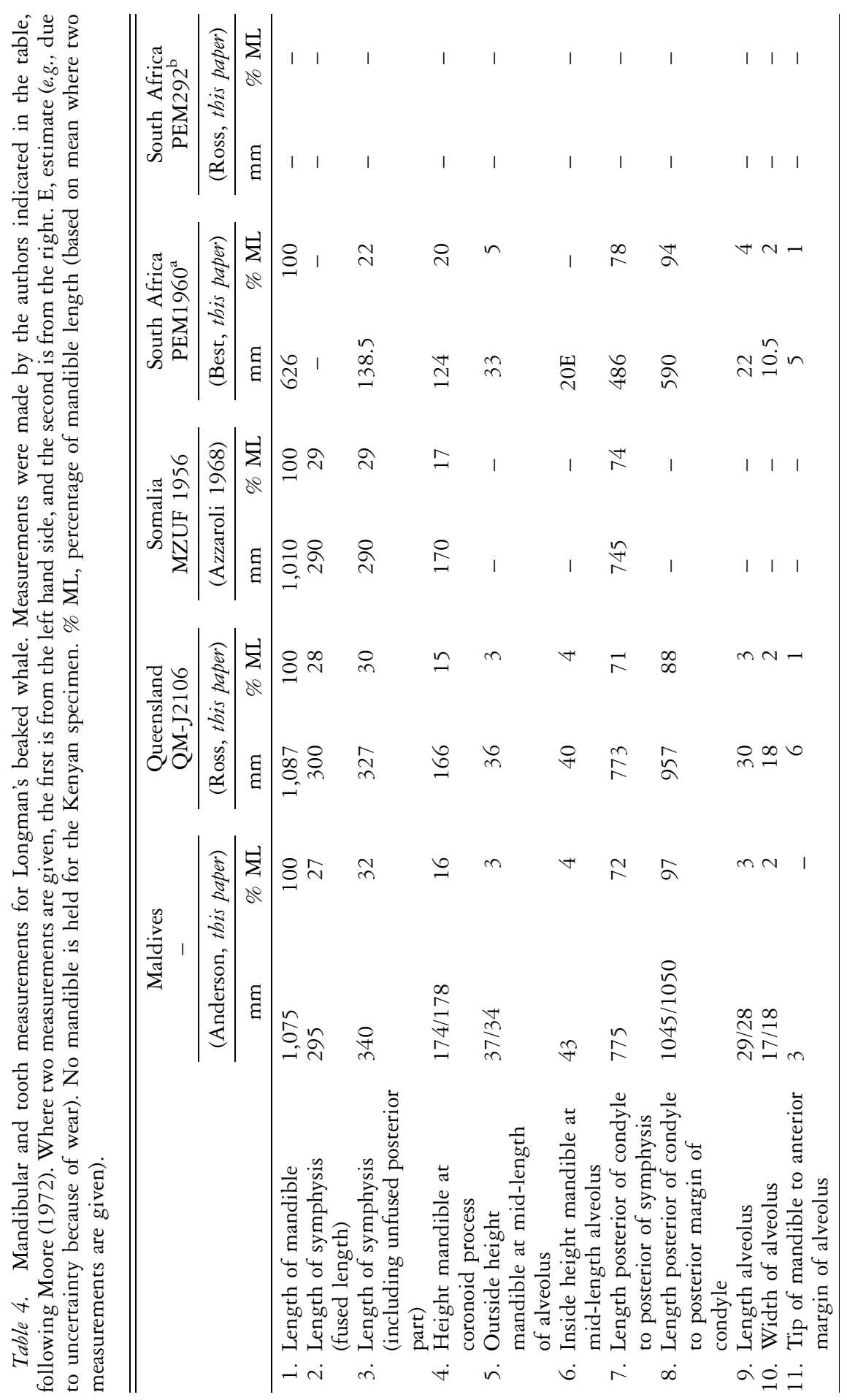




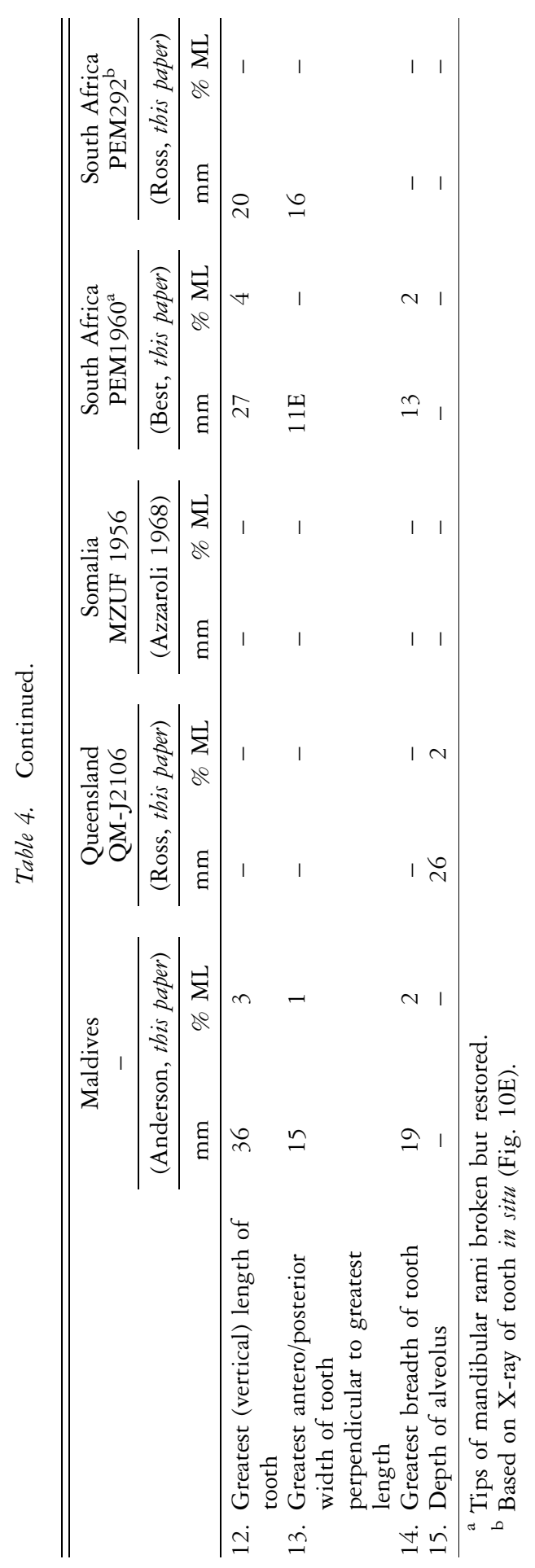


photographed at sea (see Pitman et al. 1999). The specific features listed by Pitman et al. (1999) are clearly evident in the South African specimens (Fig. 3). These include the high, white sides which are separated from the pale face and melon area by a dark band extending down from just behind the blowhole toward the flipper, and a white "ear" spot embedded within this dark band (e.g., Fig. $3 \mathrm{~A}$ this paper, circled; fig. 2C, F, Pitman et al. 1999). Dorsally, in both the specimens described in Pitman et al. (1999) and PEM292, the white of the melon extends posteriorly only as far as the blowhole. We view this matching color pattern as confirmatory evidence that the unidentified (tropical) bottlenose whale is in fact I. pacificus as suggested by Mörzer Bruyns (1971) and Pitman et al. (1999).

The dorsal fin shape of the animals pictured in Pitman et al. (1999) is also very similar to that of the South African specimens; falcate and pointed (Fig. $3 \mathrm{H}$, I, this paper; fig. 2B, Pitman et al. 1999). In some individuals, the melon shape is similar to that of the Maldivian female. However, that of others is more prominent (angle with beak $\sim 90^{\circ}$; e.g., fig. 2A, far right animal, Pitman et al. 1999). Assuming that dimorphism in melon shape follows a similar trend as in Hyperoodon spp. (e.g., Mead $1989 b)$, these latter animals may represent adult males. No erupted teeth have been observed on tropical bottlenose whales at sea (Pitman et al. 1999). However, some of the animals pictured in Pitman et al. (1999) have parallel linear scar tracks on their backs and flanks. These were likely caused by tooth rakes inflicted by conspecific males; their form is consistent with those made by a species with apical teeth. The apparent use of the teeth as "tusks" in intraspecific combat is common among beaked whales (e.g., Heyning 1984).

Analyses of mtDNA sequence data presented here have confirmed the genetic distinctiveness of Longman's beaked whale. However, further phylogenetic comparisons aimed at testing the taxonomic status of the genus Indopacetus were inconclusive. Until fresh tissue samples become available for this species, from which long sequences from slowly evolving nuclear loci can be amplified (i.e., allowing robust reconstruction of higher-level relationships among ziphiids; see Dalebout 2002), this question can be addressed only through reference to morphological features.

Moore (1968) placed Longman's beaked whale (formerly Mesoplodon pacificus) in the new genus, Indopacetus, based on four cranial characters observed in the holotype and Somali skulls, the only known specimens of this species at that time. All four of these features are also visible in the skulls of the Kenyan and South African (PEM1960) animals. Although the vertex sutures of the Maldivian specimen were not sufficiently clean for detailed examination, the rostrum form was similar to that of the other specimens. The presence of these features in all specimens of Longman's beaked whale examined to date (in particular the distinctive arrangement of the nasal and frontal bones on the vertex; e.g., Fig. 9) confirms that they are indeed diagnostic for this species, as suggested by Moore (1968). A more contentious question is whether these and other characters (summarized in Table 5) distinguish Longman's beaked whale sufficiently from other ziphiids to warrant its placement in a separate genus. (Note that only features 1-4 and 7 of Table 5 distinguish Indopacetus from all other ziphiid genera. Tooth form and alveolus depth have yet to be knowingly examined in an adult male. Conclusions regarding body form are based on qualitative assessment only).

The statements regarding the number of ribs and fused cervical vertebrae (Table 5, features 8,9 ) require discussion. Both are subject to qualification as larger sample sizes may reveal overlap with other genera. Based on the examination of three specimens, I. pacificus appears to have ten pairs of ribs. Eight to nine pairs of ribs have 
Table 5. Summary of diagnostic morphological features for Longman's beaked whale, Indopacetus pacificus.

\begin{tabular}{|c|c|c|}
\hline & Diagnostic features & Reference \\
\hline 1 & $\begin{array}{l}\text { On the vertex of the skull, the frontal bones occupy } \\
\text { an area that approximates or exceeds that occupied } \\
\text { by the nasal bones. }\end{array}$ & Moore (1968) \\
\hline 2 & $\begin{array}{l}\text { On the vertex of the skull, there is minimal } \\
\text { extension of the premaxillary crest between the } \\
\text { nasal and maxillary bones, or between the frontal } \\
\text { and maxillary bones. }\end{array}$ & Moore (1968) \\
\hline 3 & $\begin{array}{l}\text { On the dorso-lateral margin of the maxillary bone } \\
\text { above the orbit, there is a deep groove about half } \\
\text { the length of the orbit. }\end{array}$ & Moore (1968) \\
\hline 4 & $\begin{array}{l}\text { The premaxillae, as seen in dorsal view, retain an } \\
\text { even width to about the midlength of the } \\
\text { rostrum, where they may expand slightly before } \\
\text { converging again towards the tip of the rostrum. }\end{array}$ & Moore (1968) \\
\hline 5 & $\begin{array}{l}\text { Shallow alveoli (tooth sockets) compared to } \\
\text { Mesoplodon. }\end{array}$ & Moore (1968) \\
\hline 6 & $\begin{array}{l}\text { Comparatively simple cone-like teeth compared to } \\
\text { most Mesoplodon spp. }{ }^{\mathrm{a}}\end{array}$ & this paper \\
\hline 7 & $\begin{array}{l}\text { Depth of the rostrum at mid-length is } \\
\text { proportionately thinner than in other ziphiid } \\
\text { genera. }\end{array}$ & this paper \\
\hline 8 & $\begin{array}{l}\text { Ten pairs of ribs compared to Hyperoodon (eight or } \\
\text { nine). }{ }^{\mathrm{b}}\end{array}$ & this paper \\
\hline 9 & $\begin{array}{l}\text { First five cervical vertebrae fused (Mesoplodon, first } \\
\text { three fused; Hyperoodon, all seven fused). }{ }^{\mathrm{b}}\end{array}$ & this paper \\
\hline 10 & Robust body form compared to Mesoplodon. ${ }^{c}$ & this paper \\
\hline 11 & $\begin{array}{l}\text { Bulbous well-defined melon compared to Mesoplodon } \\
\text { (but similar to Tasmacetus). }\end{array}$ & this paper \\
\hline 12 & Color pattern distinct from Hyperoodon. & $\begin{array}{l}\text { Pitman et al. (1999); } \\
\text { this paper }\end{array}$ \\
\hline
\end{tabular}

${ }^{a}$ However, an adult male has yet to be knowingly examined.

${ }^{\mathrm{b}}$ Larger sample sizes may reveal overlap in these meristic characters.

${ }^{c}$ Based on qualitative evaluation only.

been recorded for Hyperoodon spp. (based on examination of eight specimens; Ross 1984, Mead 1989b), while 9-11 ribs have been recorded in Mesoplodon spp. (Mead $1989 a$ ). In the two specimens of Indopacetus for which such postcranial material was available, the first five cervical vertebrae were fused. In Mesoplodon and Berardius only the first three vertebrae are fused, comprising the atlas, axis, and third cervical (McCann 1975, Mead 1989a). In the examination of one Tasmacetus specimen the first six vertebrae were fused (Oliver 1937), while all seven cervical vertebrae have been recorded as fused in Hyperoodon (Ross 1984, Mead 1989b). Although these clear differences between genera are thought provoking, the variation observed in the genus Ziphius (four fused cervical vertebrae observed in five specimens, and three and six fused cervicals, respectively, observed in two other specimens; Omura 1972) suggests that caution should be taken in interpretation of these patterns. More information on the lesser-known ziphiid genera is clearly needed.

There appear to be three options regarding the systematic relationship of 
Longman's beaked whale to other ziphiids: Longman's beaked whale represents either a morphologically divergent form of Mesoplodon (Longman 1926, Mead 1989a) convergent on Hyperoodon in size and shape, a tropical form of Hyperoodon, or a distinct genus (Moore 1968). In addition to the features of the skull and alveoli identified by Moore (1968), five characters distinguish this species from most or all Mesoplodon spp. (Table 5). These are the depth of the rostrum, melon form (bulbous and well defined), depth of the alveoli (shallow), tooth morphology (relatively simple and conelike, at least in adult females), and body form (robust). In external morphology, Longman's beaked whale is similar to Hyperoodon. Shared features include a large bulbous melon, conspicuous blow (Pitman et al. 1999), apical teeth, a similar color pattern (especially in juveniles), and robust body form. The ontogeny of coloration is also similar, with the contrasting pale melon of neonates in both species (Fig. 3, 4) becoming less conspicuous with age. In general, the opposite trend is seen in Mesoplodon spp., with color patterning, where it exists, tending to become more conspicuous with age. (Note, however, that Mesoplodon calves may also have pale melons). However, this species is distinguished from those of the genus Hyperoodon by features of the cranial morphology (Fig. 9), including the width/depth ratio of the rostrum at mid-length (Fig. 8) and potentially in the number of ribs and fused cervical vertebrae (Table 5).

To date there has been no cladistic analysis of morphological features in this family. Although clearly of value, there is also no guarantee that such an analysis would be successful due to the low sample size and ambiguous morphology of many ziphiid species. In the absence of such morphological analyses, the polarity of different character states is difficult to determine. The lack of objective criteria in taxonomy as to how different a species must be from other related species to be considered a distinct genus is also problematic. At present, however, we see no reason on morphological grounds to overturn Moore's (1968) proposal that Longman's beaked whale is sufficiently distinct from other ziphiids to be afforded its own genus, Indopacetus.

Although I. pacificus is morphologically distinct from other ziphiid species, significant potential remains for the misidentification of these animals, both at sea and when stranded. This is due in part to its rarity, remote distribution, and similarity in external form to $H$. planifrons (the same reasons this species remained unrecognized for so long, Pitman et al. 1999), as well the overall subtlety of diagnostic features in ziphiids. Therefore, we recommend that, as well as voucher skeletal material, tissue samples, including skin biopsy samples of animals at sea, should be collected for genetic analysis wherever possible to allow confirmation of species identity. Important information regarding comparative genetic diversity, population structure, and geographic differentiation could also be obtained from such analyses.

The discovery of these four new specimens has extended the known range of Longman's beaked whale and led to the description of its external appearance for the first time. As this species is now known from six specimens, the title of the world's rarest whale must pass to the spade-toothed whale, $M$. traversii $(=M$. babamondi), which to date is known from only three specimens (two crania and one mandible with teeth, van Helden et al. 2002).

\section{ACKNOWLEDGMENTS}

We thank S. Van Dyck, Queensland Museum, Brisbane, Australia, for access to the holotype (QM-J2106); P. Agnelli, Natural History Museum, Zoological Section 'La Specola' University 
of Florence, Italy, for access to and sampling of the Somali specimen (MZUF 1956); G. Watson and staff, Port Elizabeth Museum, for the access to the South African specimens (PEM292 and PEM1960); the Sodwana Bay staff of the KwaZulu-Natal Nature Conservation Services (formerly Natal Parks Board) and the Natal Sharks Board for collection and storage of the latter specimen; and, M. Thornton, Mammal Research Institute, University of Pretoria, for reconstruction of the skull of PEM1960. For the Kenyan specimen (OM7622) we thank J. G. Mead, Smithsonian Institution National Museum of Natural History, Washington, DC, for literature research assistance; R. V. Salm, The Nature Conservancy, Honolulu, Hawaii, for assistance with identification and contacting marine specialists; and J. Salm, B. Lyons and K. ole-MoiYoi for initial attempts in measuring the specimen. We thank A. Shaan, I. Nadheeh, I. Naeem, A. Hafiz, and Z. Waheed, Marine Research Centre, Malé, for help with the Maldivian specimen; I. MacDonald, University of Auckland, for photographs of the tooth, J. Jamieson, Auckland Hospital Radiology Department for X-rays of the tooth, and R. Tucker, Kohimara Veterinary Clinic, Auckland, New Zealand, and Dr. F. Verstraete, Department of Radiological and Surgical Sciences, University of California Davis Veterinary School, for further evaluation of tooth development. We thank A. G. Rodrigo, Univeristy of Auckland, for advice regarding phylogenetic analysis, A. Dodd, C. Olavarria, and D. Steel for aid with logistics, and J. G. Mead for additional discussion regarding the morphological distinctiveness of Indopacetus. We thank the Director, ABRS, Environment Australia, Canberra, for approval to publish drawings of the vertex in beaked whales, from Fauna of Australia, Vol. 1B, Mammalia. We thank W. F. Perrin and an anonymous reviewer for their constructive comments on the manuscript. We also thank those who provided access to the validated specimens used to establish the beaked whale DNA reference database which has been so valuable for these and other discoveries. MLD was supported by a fellowship from the International Fund for Animal Welfare (IFAW), and doctoral scholarships from the University of Auckland and New Zealand Vice-Chancellors' Committee (William Georgetti Scholarship). PBB acknowledges support from the National Research Foundation, South Africa. This project was supported by grants to CSB from the University of Auckland, the New Zealand Lottery Board, the New Zealand Marsden Fund, the International Fund for Animal Welfare, and the New Zealand Vice Chancellor's Fund.

\section{Literature Cited}

Arnason, U., A. Gullberg and B. Widegren. 1991. The complete nucleotide sequence of the mitochondrial DNA of the fin whale, Balaenoptera physalus. Journal of Molecular Evolution 33:556-568.

Azzaroli, M. L. 1968. Second specimen of Mesoplodon pacificus, the rarest living beaked whale. Monitore Zoologico Italiano (N. S.) 2:67-79.

Baker, A. N. 1999. Whales \& dolphins of New Zealand and Australia: An identification guide. Victoria University Press, Wellington.

Baker, C. S., A. Perry, J. L. Bannister, M. T. Weinrich, R. B. Abernethy, J. Calambokidis, J. Lien, R. H. Lambertsen, J. Urban Ramirez, O. Vasquez, P. J. Clapham, A. Alling, S. J. O’Brien and S. R. Palumbi. 1993. Abundant mitochondrial DNA variation and world-wide population structure in humpback whales. Proceedings of the National Academy of Sciences of the United States of America 90:8239-8243.

Baker, C. S., F. Cipriano AND S. R. Palumbi. 1996. Molecular genetic identification of whale and dolphin products from commercial markets in Korea and Japan. Molecular Ecology 5:671-685.

Ballance, L. T., And R. L. Pitman. 1998. Cetaceans of the western tropical Indian Ocean: Distribution, relative abundance, and comparisons with cetacean communities of two other tropical ecosystems. Marine Mammal Science 14:429-459.

Cockcroft, V. G., G. J. B. Ross, A. D. Connell, B. D. Gardner and A. C. Butler. 1991. Occurrence of organochlorines in stranded cetaceans and seals from the east coast of Southern Africa. Pages 271-276 in S. Leatherwood and G. P. Donovan, eds. Cetaceans 
and cetacean research in the Indian Ocean Sanctuary. United Nations Environment Programme, Nairobi.

Dalebout, M. L. 2002. Species identity, genetic diversity and molecular systematic relationships among the Ziphiidae (beaked whales). Ph.D. thesis, School of Biological Sciences, University of Auckland, Auckland, New Zealand. 385 pp. +7 appendices.

Dalebout, M. L., A. Van Helden, K. Van Waerebeek and C. S. Baker. 1998. Molecular genetic identification of southern hemisphere beaked whales (Cetacea: Ziphiidae). Molecular Ecology 7:687-694.

Dixon, J. M. 1970. Two new whale records from Victoria, Mesoplodon bowdoini Andrews (Ziphiidae) and Balaenoptera edeni Anderson (Balaenopteridae). The Victorian Naturalist 87:88-93.

Gallo-Reynoso, J. P., and A. L. Figueroa-Carranza. 1995. Occurrence of bottlenose whales in the waters of Isla Guadalupe, Mexico. Marine Mammal Science 11:573-575.

Goodall, R. N. P. 1978. Report on small cetaceans stranded on the coasts of Tierra del Fuego. Scientific Reports of the Whale Research Institute, Tokyo 30:197-230.

Henshaw, M. D., R. G. Leduc, S. J. Chivers and A. E. Dizon. 1997. Identification of beaked whales (family Ziphiidae) using mtDNA sequences. Marine Mammal Science 13:487-495.

Heyning, J. E. 1984. Functional morphology involved in intraspecific fighting of the beaked whale, Mesoplodon carlhubbsi. Canadian Journal of Zoology 62:1645-1654.

Heyning, J. E. 1989. Cuvier's beaked whale, Ziphius cavirostris G. Cuvier, 1823. Pages 289307 in S. H. Ridgway and R. Harrison, eds. Handbook of marine mammals. Volume 4. Academic Press, London.

Höss, M., AND S. PÄÄBO. 1993. DNA purification from Pleistocene bones by a silica-based purification method. Nucleic Acids Research 21:3913-3914.

Jefferson, T. A., S. Leatherwood and M. A. Webber. 1993. FAO species identification guide: Marine mammals of the world. United States Environment Programme; Food and Agriculture Organization of the United Nations (FAO), Rome.

JONES, E. C. 1971. Isistius brasiliensis, a squaloid shark, the probable cause of crater wounds on fishes and cetaceans. Fishery Bulletin US 69:791-798.

Kasuya, T., AND M. Nishiwaki. 1971. First record of Mesoplodon densirostris from Formosa. Scientific Reports of the Whales Research Institute, Tokyo 23:129-137(plus plates).

Longman, H. A. 1926. New records of Cetacea, with a list of Queensland species. Memoirs of the Queensland Museum 8:266-278.

Matisoo-Smith, E., J. S. Allen, T. N. Ladefoged, R. M. Roberts and D. M. Lambert. 1997. Ancient DNA from Polynesian rats: Extraction, amplification and sequence from single small bones. Electrophoresis 18:1534-1537.

McCann, C. 1962a. Key to the family Ziphiidae, beaked whales. Tuatara 10:13-18.

McCann, C. 1962b. The taxonomic status of the beaked whale Mesoplodon hectori (Gray) Cetacea. Records of the Dominion Museum 4:83-94.

McCann, C. 1962c. The taxonomic status of the beaked whale Mesoplodon pacificus Longman-Cetacea. Records of the Dominion Museum 4:95-100.

McCann, C. 1975. A study of the genus Berardius. Scientific Reports of the Whales Research Institute, Tokyo 27:111-137 plus plates.

McCann, C., AND F. H. Talbot. 1963. The occurrence of True's beaked whale (Mesoplodon mirus True) in South African waters, with a key to South African species of the genus. Proceedings of the Linnaean Society, London 175:137-144.

Mead, J. G. 1989a. Beaked whales of the genus Mesoplodon. Pages 349-430 in S. H. Ridgway and R. Harrison, eds. Handbook of marine mammals. Volume 4. Academic Press, London.

MeAD, J. G. 1989b. Bottlenose whales, Hyperoodon ampullatus (Forster, 1770) and Hyperoodon planifrons Flower, 1882. Pages 321-348 in S. H. Ridgway and R. Harrison, eds. Handbook of marine mammals. Volume 4. Academic Press, London. 
MeAd, J. G. 1989c. Shepherd's beaked whale, Tasmacetus shepherdi Oliver, 1937. Pages 309320 in S. H. Ridgway and R. Harrison, eds. Handbook of marine mammals. Volume 4. Academic Press, London.

Mead, J. G., W. A. Walker and W. J. Houck. 1982. Biological observations on Mesoplodon carlhubbsi (Cetacea: Ziphiidae). Smithsonian Contributions to Zoology 344:1-25.

Miyasaki, N., I. Nakamura, T. S. and R. Tatsukawa. 1987. A stranding of Mesoplodon stejnegeri in the Maizuru Bay, Sea of Japan. Scientific Reports of the Whales Research Institute, Tokyo 38:91-105.

MoORE, J. C. 1957. Differences between the beaked whales Mesoplodon mirus and Mesoplodon gervaisi. American Museum Novitates 1831:1-25.

MoORE, J. C. 1963. Recognizing certain species of beaked whales of the Pacific Ocean. American Midland Naturalist 70:396-428.

MOORE, J. C. 1968. Relationships among the living genera of beaked whales. Fieldiana Zoology 53:209-298.

MoOre, J. C. 1972. More skull characters of the beaked whale Indopacetus pacificus and comparative measurements of austral relatives. Fieldiana Zoology 62:1-19.

Mörzer Bruyns, W. F. J. 1971. Field guide of whales and dolphins. C. A. Mees, Amsterdam.

Nishiwaki, M., AND T. KamiYA. 1958. A beaked whale Mesoplodon stranded at Oiso Beach, Japan. Scientific Reports of the Whales Research Institute, Tokyo 13:53-83.

NorRIS, K. S. 1961. Standardised methods for measuring and recording data on the smaller cetaceans. Journal of Mammalogy 42:471-476.

Oliver, W. R. B. 1937. Tasmacetus shepherdi, a new genus and species of beaked whale from New Zealand. Proceedings of the Zoological Society of London, Series B:371-381, pl. I-V.

Omura, H. 1972. An osteological study of the Cuvier's beaked whale, Ziphius cavirostris, in the Northwest Pacific. Scientific Reports of the Whales Research Institute, Tokyo 24:1-34.

РёÄво, S. 1990. Amplifying ancient DNA. Pages 159-166 in M. A. Innis, D. H. Gelfand, J. J. Sninsky and T. J. White, eds. PCR protocols: A guide to methods and applications. Academic Press, San Diego, CA.

Palumbi, S. R. 1996. Nucleic acids II: The polymerase chain reaction. Pages 205-247 in D. M. Hillis, C. Moritz and B. K. Mable, eds. Molecular aystematics. Sinauer Associates, Sunderland, MA.

Perrin, W. F., ANd A. C. Myrick, Eds. 1980. Age determination of toothed whales and sirenians. Report of the International Whaling Commission, Special Issue 3.

Pichler, F. B., M. L. Dalebout and C. S. Baker. 2001. Non-destructive DNA extraction from sperm whale teeth and scrimshaw. Molecular Ecology Notes 1:106-109.

Pitman, R. L., D. M. Palacios, P. L. Brennan, K. C. III. Balcomb and T. Miyashita. 1999. Sightings and possible identity of a bottlenose whale in the tropical Indo-Pacific: Indopacetus pacificus? Marine Mammal Science 15:531-549.

Raven, H. C. 1937. Notes on the taxonomy and osteology of two species of Mesoplodon (M. europaeus Gervais, M. mirus True). American Museum Novitates 905:1-30.

Reyes, J. C., J. G. Mead and K. Van Waerebeek. 1991. A new species of beaked whale Mesoplodon peruvianus sp. n. (Cetacea: Ziphiidae) from Peru. Marine Mammal Science 7:1-24.

RicE, D. W. 1998. Marine mammals of the world: Systematics and distribution. Special Publication 4. The Society for Marine Mammalogy, Lawrence, KS.

Ross, G. J. B. 1984. The smaller cetaceans of the south east coast of southern Africa. Annals of the Cape Provincial Museum (Natural History) 15:173-410.

Ross, G. J. B., AND R. M. TIETZ. 1972. Records of Cuvier's beaked whales from South Africa. Annals of the Cape Provincial Museum (Natural History) 9:1-10.

Scott, H. H., And C. E. LoRd. 1920. Studies of Tasmanian Cetacea. Part II. Papers and Proceedings of the Royal Society of Tasmania 1919:23-32. 
SwOFFord, D. L. 1999. PAUP*: Phylogenetic analysis using parsimony (and other phylogenetic reconstruction methods). Sinauer, Sunderland, MA.

Van Helden, A. L., A. N. Baker, M. L. Dalebout, J. C. Reyes, K. Van Waerebeek and C. S. BAKER. 2002. Resurrection of Mesoplodon traversii (Gray, 1874), senior synonym of M. bahamondi Reyes, Van Waerebeek, Cárdenas and Yáñez, 1995 (Cetacea: Ziphiidae). Marine Mammal Science 18:609-621.

Walsh, P. S., D. A. Metzger and R. Higuchi. 1991. Chelex-100 as a medium for simple extraction of DNA for PCR-based typing from forensic material. BioTechniques $10: 506-513$

Wilson, A. C., R. L. Cann, S. M. Carr, M. J. George, U. B. Gyllensten, K. Helm-bychowski, R. C. Higuchi, S. R. Palumbi, E. M. Prager, R. D. Sage and M. Stoneking. 1985. Mitochondrial DNA and two perspectives on evolutionary genetics. Biological Journal of the Linnean Society, London 26:375-400.

Zerbini, A. N., AND E. R. Secchi. 2001. Occurrence of the Hector's beaked whale, Mesoplodon hectori in Southern Brazil. Aquatic Mammals 27:149-153.

Received: 5 March 2002

Accepted: 14 November 2002

\begin{abstract}
APPENDIX
DNA Amplification

MtDNA control region primers-M13-Dlp1.5-L (5'-TGTAAAACGACGGCCAGTTCACCCAAAGCTGRARTTCTA- $3^{\prime}$; Dalebout et al. 1998); Dlp5-H (5'-CCATCGW GATGTCTTATTTAAGRGGAA- 3'; Dalebout et al. 1998); Dlp4-H (5' GCGGGWTRYTG RTTTCACG- 3'; C. S. Baker, unpublished); Dlp10-L (5'-CCACAGTACTATGTCCGTATT- 3'; Baker et al. 1993). Product sizes (beaked whales): M13-Dlp1. 5-L and Dlp5-H, 500 bp; M13-Dlp1.5-L and Dlp4-H, 350 bp; Dlp10-L and Dlp4-H, $\sim 280 \mathrm{bp}$.

MtDNA cytochrome b primers - CB1-L(5' -CCATCCAACATCTCAGCATGATGAAA- 3'; Palumbi 1996); CB2-H (5' -CCCTCAGAATGATATTTGTCCTCA- 3'; Palumbi 1996); CYBMF-L (5'-GAACTATAAGAACA CTAATGACCAA- $3^{\prime}$; Dalebout 2002). CYBMR-H (5' -TGATTCAGCCATAGTTAACGTCTCGAC- 3'; Dalebout 2002). Product sizes: CB1-L and CB2-H, $\sim 300 \mathrm{bp}$; CYBMF-L and CYBMF-H, $\sim 230 \mathrm{bp}$. The latter two primers are beaked whale specific and were designed to avoid amplification of modern human mtDNA, a frequent contaminant of historic skeletal material.

PCR amplification and sequencing followed standard protocols (Palumbi 1996), except for the addition of bovine serum albumin (BSA) solution $(0.5-1 \mu \mathrm{g} / \mu \mathrm{l})$ to help overcome the effect of the inhibiting substances that often accumulate in historical material (Päbo 1990). For both loci, amplification of the larger fragment was attempted first, which if unsuccessful, was followed by attempts to amplify successively smaller fragments. These shorter fragments nest within the larger fragment characterized for each locus. A primer map is available from the website, http://www.DNA-surveillance.auckland.ac.nz.
\end{abstract}

\title{
Phylogenetic Analyses
}

Neighbour-joining-Kimura 2-parameter corrected distance, gamma shape parameter $=$ 0.5 ; Missing sites and gaps ignored for affected pairwise comparisons; 1,000 neighbourjoining bootstrap replicates. 
Maximum parsimony-Heuristic search with sub-tree pruning-regrafting (SPR) branch swapping and random sequence addition, 10 replicates. Control region, nine trees found (consistency index [CI], 0.405; retention index [RI], 0.748); cytochrome $b, 122$ trees found (CI, 0.405; RI, 0.748); 10,000 fast heuristic bootstrap replicates.

Maximum likelibood-All starting parameters for an HKY85+G+I model of sequence evolution (different rates for transition and transversion substitutions, unequal base composition, substitution rates vary among sites, some sites invariant) were estimated from neighbour-joining trees. Heuristic search with SPR branch swapping and random sequence addition, 10 replicates; 200 fast heuristic bootstrap replicates. 